\title{
The Final Steps: From Heretics to the Saved Sect
}

After what would have been something of a fifteen-day journey, ${ }^{1}$ al-Wāsițī entered Cairo, the place that eventually turned out to be the turning point in his search for spiritual guidance in the sense that it pushed him to his final destination, Damascus. Since these were the last stages of his journey, his experiences in these two cities also comprise the last sections of his autobiography. The current chapter is therefore split into two parts: the first examines his account of the Egyptian capital and the Sufi convents he stayed in there, and the second follows the final years of his life spent in Damascus as a teacher of his own formulation of traditionalist Sufism. As I have noted before, we do not know when he entered Cairo and how long he subsequently stayed there. We do know that he must have already settled in Damascus in 699/1300, so that it is likely that he spent his time in Cairo somewhere during the nineties.

In his autobiography al-Wāsițī differentiates between two categories of Sufis he found residing in Cairo's convents. He calls the first group "sūfiyyat al-rasm," i.e. those who are Sufi only by carrying out the conventions of Sufism, a term that is actually coined by Ibn Taymiyya as well. ${ }^{2}$ The second group may be identified as those Sufis who either adhered to the Akbarian school or were close to it in doctrine, all of whom our Iraqi Sufi considers monists (al-ittihādiyya). Both the Sufis of convention and the Akbarians will be further examined below on the basis of al-Wāsițī's writings and several relevant primary and secondary sources. As we shall see, we are once more confronted with some difficulty in contextualizing what he tells us about both groups due to the meagre information he provides us with. There are nevertheless useful clues to be found in his account that will help us elaborate on the background of these two trends of Sufism that had apparently become successfully established in early Mamluk Cairo.

1 Udovitch, "Alexandria in the 11th and 12th Centuries," p. 102.

2 To my knowledge, Ibn Taymiyya only uses the term once (see: $M F$, vol. 11, p. 19). Whether it was appropriated by al-Wāsițī or the other way around remains impossible to establish. 


\subsection{The Sufis of Convention}

We have previously seen that, as the capital, Cairo was the economic and political center of the Mamluk sultanate. While I have argued that Alexandria may for a part of the seventh/thirteenth century be regarded as the Sufi capital of Egypt, mostly due to the distinct presence and activity of renowned Sufi shaykhs, by no means did I imply that Cairo was not an important center of Sufism as well. On the contrary, it was full of Sufi activity. In all its different, and sometimes opposing, manifestations, Sufism was undoubtedly already a fundamental part of the daily lives of many Cairenes when al-Wāsițī came to the city. When it comes to Cairo's scholars and students of religious knowledge this can be observed by merely looking at the many examples of religious institutions where Sufism was taught as one of the Islamic sciences. ${ }^{3}$ For the common citizen the link with Sufism is evident from the great numbers that flocked to Sufi shaykhs who were widely acknowledged as friends of God, or 'awliya $\bar{a}$ ' Allāh.' Their distinguished position was considered a source of blessing (bara$k a)$ that could be of benefit even after their passing by visiting their graves. ${ }^{4}$ As for the governing powers, their involvement with Sufism in Egypt became manifest most clearly for the first time in Cairo under the Ayyubids. It was then that Șalāh al-Dīn established the Dār Saīd al-su'adā', also known as the Salāhiyya, the first khānqāh of Egypt that served as a center for the so-called "state-sponsored" Sufism. For a considerable time this convent was headed by the country's chief Sufi shaykh, the shaykh al-shuyükh, who was appointed and salaried by the Ayyubids, a practice that the Mamluks continued. ${ }^{5}$ We could thus say that, like Alexandria, Cairo had become an important center of Sufism at the time of al-Wāsițī's travels, so that it was indeed no exceptional decision for a wandering Sufi to have an interest in the city.

Although there are several instances where al-Wāsiți tells us that he had at one point in his life lived in Sufi convents, he never mentions any by name. In the first sentence of the section on the șüfiyyat al-rasm in his autobiography we find him stating rather ambiguously that after his days among the Alexandrian Sufis he settled in 'the convent' (al-ribātt). ${ }^{6}$ It could very well be that his use of

3 On the presence of Sufism in the formal curriculum of Islamic institutions in the Mamluk period, see for instance: Berkey, The Transmission of Knowledge, chapter 3.

4 On the role of Sufism among "ordinary" citizens, see for instance: Shoshan, Popular Culture, chapter 1.

5 On the history of this khānqah, see for instance: Leonor E. Fernandes, The Evolution of a Sufi Institution in Mamluk Egypt: The Khanqah (Berlin: Klaus Schwarz Verlag, 1988), pp. 21-25. On the position of the shaykh al-shuyūkh, see: Nathan Hofer, "The Origins and Development of the Office of the "Chief Suf" in Egypt, 1173-1325." Jss 3 (2014): pp. 1-37.

6 Al-Wāsițī, Rihla, p. 37. 
the term ribät is significant here in view of his Iraqi background. In parts of Iraq, especially west of Baghdad, it was quite common to use the term ribāt to refer to the "state-sponsored" Sufi institution, known in Egypt as the khānqāh. ${ }^{7}$ It is perhaps no coincidence that al-Dhahabi uses the word khānqāhs (khawāniq) rather than ribāts (rubuț) when he relates that our Iraqi Suf lived in Sufi convents for some time. ${ }^{8}$ It may very well have been specifically the institutions sponsored by the sultanate that he attended in Cairo, which would certainly have been a logical choice at that time.

There are in fact two indications in al-Wāsiți’s writings that the above-mentioned Sa'ìd al-su'adā was one of them. This khānqāh could house up to 300 people and was primarily meant for Sufis from abroad, particularly those of a Shāfíi-Ash'arī denomination, as attested to by its endowment deed (waqfìya). In practice, it especially attracted Muslims of Persian origin coming from the east, the majority of whom we know adhered to the latter schools of law and theology respectively. ${ }^{9}$ Sufis who traveled to the Saīd al-su'adā would stay for varying lengths of time. Some would come to study with reputable scholars who taught and transmitted books from there, while others simply wanted to find out what Cairo had to offer them. ${ }^{10}$ As an Iraqi Shāfíi and a Sufi in search of guidance, this could thus have been an environment that initially appealed to al-Wāsiți. His own account only very briefly touches upon what it was that convinced him to join the company of the convent's Sufis, where he states that "something of lights shone [with them] so I accompanied them and found [sic] them speaking about the remembrance of God (dhikr), spiritual seclusion (khalwa), the study of religious knowledge, and devotion to worship."11 Nothing more is found in any of his works regarding his motivation.

The first instance where he may be revealing indirectly that it was the Said al-su'adā where he stayed is found in his Talqị̂ al-afhām. In it he mentions that one of the characteristics of the Sufis he encountered in the convent was that "they love to show off their appearance (hay'a) to the common people (al'awāmm) on Fridays and gatherings." 12 Now, according to the Egyptian historian al-Maqrīzì (d. 845/1442), the people of Fusțāt (mișr) would come to Cairo on Fridays especially to watch the Sufis of the Sa'id al-su'adā proceed to the Ḥākimī Jāmic', believing that they obtained blessings therefrom. These Sufis,

$7 \quad$ Homerin, "Saving Muslim Souls," pp. 61-63.

8 Note that in the printed edition the word khawāniq is written as khawānik with the letter kāf instead of $q \bar{a} f$, cf. al-Dhahabī, Dhayl Tärīkh, p. 126.

9 Hofer, The Popularisation of Sufism, p. 69.

$10 \quad$ Ibid. p. 68.

$11 \quad$ Al-Wāsițī, Rihlala, p. 37.

12 Al-Wāsițī, Talqūh al-afhām, p. 16o. 
al-Maqrizi continues, "would have an eminent appearance (hay'a fädila) on [these] Fridays." ${ }^{\prime 3}$ It is thus very well possible that it were exactly these processions from the Sa'īd al-su'adā that al-Wāsițī was referring to in Talqūh al-afhām.

The second indication that he stayed in the Sa'ìd al-su'adā is found in his autobiography. In the section on the monistic Sufis he says to have met in Cairo's convents, he attempts to discredit their doctrine through the following example:

When they go to see a king or someone with public authority (șăhib walāya), they address him and implore him as if they are imploring God. That is because, in their view, he is a manifestation of [God's] being (mazhar wujüdihi), so they are in fact addressing the 'divine being' (alwujūd) inside of him. Hence, one of their shaykhs would say to al-Shujāìi, who was a vice-regent known for tyranny and aggression: "You are the supreme name of God (anta ism Allāh al-a'zam)," and other such things! $!^{14}$

The vice-regent he is referring to here is 'Alam al-Dīn Sanjar al-Shujāî̀, a controversial Mamluk amir who was put to death in 693/1293 by supporters of Zayn al-Dīn Kitbughā, a rival amir who later became sultan. ${ }^{15}$ According to the chronicles, he was indeed known among the people as an oppressor. He was in fact so hated that, after he was executed, they beat his severed head as it was paraded around Cairo on a spear. ${ }^{16}$ Now, we know that this amir had friendly relations with one al-Aykī, a shaykh of the Akbarian school to whom we will return shortly in the next section. Al-Shujāî is said to have favored him "to the extent that he would let him sit higher than him (kāna yu'qiduhu fawqa minhu)." ${ }^{\prime 17}$ And it was reportedly thanks to his influence that al-Ayki became head of the Sa'īd al-su'adā' when he was formally appointed shaykh al-shuyükh in $684 / 1285$, a position he held until he was dismissed somewhere between

13 Taqī al-Dīn Aḥmad b. 'Alī al-Maqrīzī, al-Mawāiciz wa-al-ítibār bi-dhikr al-khițaț wa-alàthār (Beirut: Dār al-kutub al-ilmiyya, 1997), vol. 4, p. 283.

14 Al-Wāsițī, Rị̣la, p. 41.

15 Ibn Taghrī Birdī, al-Nujūm al-zāhira, vol. 7, p. 384; al-Maqrīzì, al-Sulūk, vol. 2, p. 226. AlShujāî's bad reputation is also noted by Northrup several times in From slave to sultan, see for instance pp. 121-123, 140, and 218. al-Maqrīzī, al-Sulūk, vol. 2, pp. 254-255. The circumstances leading up to al-Shujāî̀'s execution are studied in detail by Amir Mazor, The Rise and Fall of a Muslim Regiment: The Manșüriyya in the First Mamluk Sultanate, 678/1279-741/1341 (Göttingen, Niedersachs: V\&R unipress, 2015), pp. 86-89.

17 Shams al-Dīn Muhammad b. Ibrāhīm al-Jazarī, Ta'rīkh ḥawādith al-zamān wa-anbā̉ihi wawafayāt al-akābir wa-al-a'yān min abnāihi, ed. 'Umar Tadmurī (Beirut/Șaydā: al-Maktaba al-'așriyya, 1998), vol. 1, p. 403 . 
687/1288 and 692/1292. ${ }^{18}$ With that in mind, it is not farfetched to think that the Sufi shaykh referred to by al-Wāsiți in the above-quoted remark may actually have been al-Ayki. If so, this would indicate that his autobiography's section on the monistic Sufis in the convents of Cairo was in all likelihood at least partially based on what he had witnessed in the Saî̀ al-su'adā'.

Either way, life within the confinements of the Sufi convent confronted alWāsiți once more with what he considered to be major flaws in the practice of Sufism in his age. His criticism towards the convent's inhabitants is reminiscent of what we have seen in his account of the Sufis he accompanied in Baghdad. At the heart of the label 'Sufis of convention' was his conviction that they failed to realize that the practice of Sufism ought to be a means to an end, and not the end itself. The label is perhaps explained most distinctly in Talqị alaftham, where he elaborates on what he means when he says that they are "obsessed with conventions" (al-'âkifün 'alà al-rusūm):

[They are] obsessed with what the group $(t \bar{a} i f a)$ has established, pertaining to conventional habits. They have made conventions regarding entering and leaving, sitting and moving, clothing and turbans. They view anything contradicting [their conventions] as something reprehensible, as if a $\sin .^{19}$

For al-Wāsițī, the supervised, orchestrated communal life in the khānqāh was the crux of the problem, because it resulted in behavior that was not purely for the sake of God. In his autobiography he describes the convents' Sufis as follows:

I found a people who are concerned with outward image, the marks of prostration on their foreheads, their appearance (hay'a), ornaments

The historian Ibn al-Furāt (d. 807/1405) may be implying that al-Aykī was dismissed in 69o/1291 in Tārīkh Ibn al-Furāt, pp. 123-124, while another historian, al-'Aynī (d. 1451/855), seems to imply that this occurred in 692/1292, cf. Badr al-Dīn Mahmūd al-'Aynī, Iqd aljumān fì tārīkh ahl al-zamān ('aṣr salāțīn al-mamālēk), ed. Muhammad Muḥammad Amīn et al. (Cairo: Dār al-kutub wa-al-wathāiiq, 2010), vol. 3, p. 179. It must be noted that neither of these two sources explicitly mention a date, but both discuss al-Ayki's dismissal in the entry of the year I have mentioned. We must also consider that al-Aykìs successor as shaykh al-shuyūkh, Ibn Bint al-A'azz, was deposed of all his positions save one in the year 69o/1291, cf. al-Dhahabī, Tärïkh, vol. 51, p. 55. Secondary sources also differ on the date of al-Ayki's dismissal, with the year 687/1288 mentioned by both Hofer, The Popularisation of Sufism, p. 65 and Homerin, "Saving Muslim Souls," p. 66. However, Hofer gives the year 689/129o in: "The Origins," p. 27. 
(ashkāl), and having their beards combed.... I found that their hearts are filled with the actions of their brothers. ${ }^{20}$

In other words, while they display the poverty of the Sufis (faqr) outwardly, they disregard work on their inner being $(b \bar{a} t \underline{t i n})$. He therefore refers to them in several other writings as "the people of outward appearance" (ahl al-ziyy) and their shaykhs as "Sufi masters in outward appearance only" (mashāyikh alziyy). ${ }^{21}$ For the most part their concern is for worldly matters, he says, for they are bent on preserving their own position and status. His main complaint in that regard is that that they put in sincere effort only to uphold the favor of their Mamluk patrons, who provide them with the stipends (sing. manșab, pl. manāsib) to preserve their life in the convent. ${ }^{22}$

As in most cases thus far, there is a historical reality to these descriptions if we examine other relevant sources. Because the situation of the khānqāh in Mamluk Egypt has been studied in some detail, we may to some degree historicize the picture al-Wāsiți has sketched for us above. We know, for instance, that there were indeed highly ritualized routines in which inhabitants of a khānqāh had to participate. The resident Sufi would have specific religious obligations to fulfill individually in his own cell, imposed by either the establishment's endower (wāqif) or its head shaykh. There were also specific communal practices that were incumbent upon each Sufi, such as the congregational prayers five times a day and their wazi $\bar{f} a$, the daily ritual duty that increasingly consisted of what came to be known as hudür. The latter term signified a gathering during which God would be remembered in a stipulated way, by reciting the Qur'an or through specific invocations, followed by the recital of Sufi poetry. During his visit to Cairo, Ibn Batțūța witnessed such sessions which, according to his Rihla, took place twice a day, once after the morning prayer (al-șubh), and once after the afternoon prayer $\left(a l-{ }^{\prime} a s ̧ r\right) .{ }^{23}$ Al-Wāsițī may very well be referring to this same ritual in his autobiography where he states that a Sufi who lives in the convent is fearful of skipping his afternoon ritual duty (waziffat al-'așr), lest his reputation be ruined, or worse, he be expelled from the convent. ${ }^{24}$ That, as implied here, a close record was being kept of everyone's participation in the daily routines is actually attested to by the fact that

\footnotetext{
$20 \quad$ Al-Wāsițī, Riḥla, p. 37.

21 Al-Wāsițī, Talqūh al-afhām, p. 158; Mīzān al-shuyūkh, p. 232; Mukhtaṣar sīrat rasūl Allāh, f.2b. where he refers to these Sufis as the Rasmiyya in a letter to several of his companions.

23 Ibn Bațtūța, Riḥla, vol. 1, p. 204.

24 Al-Wāsițī, Riḥla, p. 37.
} 
endowers of convents would appoint a so-called kātib ghaybat al-șūfiyya, a scribe who noted those Sufis who were absent during the communal obligations. ${ }^{25}$ Another observation made by al-Wāsiți that has a historical basis is his allusion to the financial dependency of the convents' Sufis on Mamluk officials. In the past, some scholars in Mamluk studies have dismissed such a dependency. However, more recently scholars such as Nathan Hofer and Emil Homerin have convincingly shown that the Sufis of the khānqāh were indeed reliant on the Mamluk sultanate for their livelihood. ${ }^{26}$

Finally, al-Wāsițì's negative depiction of the convents' shaykhs as charlatans who only look like Sufi masters outwardly perhaps reflects that, in practice, it was not required to be a Sufi of great renown to become head of a khānqāh. Since the position was actually quite lucrative, competition for it was fierce. We thus find that it would sometimes be granted to a jurist with no particular Sufi credentials, and that this was often on the basis of a relationship that the appointee had with the wäqif prior to the appointment. ${ }^{27}$

Under these circumstances al-Wāsiți would undoubtedly have felt that his life in Cairo was in no way a step forward from the Shādhiliyya. Matters soon went from bad to worse as he discovered a relatively new trend of Sufism that had gained favor among a group of the Sufis living with him in the convents. This was the Akbarian school of Ibn 'Arabī, whose followers al-Wāsițī viewed as sheer monists. He understood their presence in terms of what was to him the very core of the affliction that plagued the Cairene convents, namely, their focus on conventions:

They [the inhabitants of the convents] have something of the Mongols' disposition, for they accept anyone who upholds the conventions [of Sufism], be it a monist (ittihād $\bar{l}$ ) or heretic. They will not object to him. That is why the followers of Șadr al-Dīn al-Qūnawī and Ibn 'Arabī (al-șadriyya wa-al-arabiyya) are ever in their presence, in spite of the fact that they are aware of their deviancy (inhiräf)! Now, the same goes for the Mongols: they accept anyone who obeys [them], be it a Jew or a Christian. ${ }^{28}$

To judge someone's state as a Sufi merely by appearance or by his or her practice of Sufi rituals, without concern for sound doctrine, was a great threat to pure, unadulterated Sufism in al-Wāsițî's eyes. It was a threat that opened

Fernandes, The Evolution, pp. 54-56.

26 Hofer, The Popularisation of Sufism, p. 78; and: Homerin, “Saving Muslim Souls," p. 69.

27 Homerin, "Saving Muslim Souls," p. 70.

28 Al-Wāsițī, Riḥla, p. 38. 
doors to what he would come to recognize as one of the most dangerous manifestations of the Sufi path.

\section{$1.2 \quad$ The Heresy of the Ittihādiyya}

After having described the Sufis of convention, al-Wāsitịis autobiography proceeds with a new section to introduce the convents' ittihaddiyya, or monistic Sufis, who are portrayed as a distinct Sufi țăiffa. This section starts right away with setting forth his own understanding of their doctrine:

While living in the convents (al-rubut) I was confronted by a group ( $t \bar{a} i f f a)$ who talk about divine love (mahabba) and divine unity (tawhìd), to which they refer by saying: "This one is a monotheist (muwahhid), but that one understands nothing of [God's] unity." They magnify their level of tawhìd and ask who is able to reach it, then name their own shaykhs, such as Ibn 'Arabī and al-Ṣadr al-Qūnawì.

I stayed for some time to examine this tawhìd that they allude to. I concluded that the gist of it is that they believe the Real (T) to be nondelimited existence, permeating all created things (al-wujūd al-muțlaq $a l-s \bar{a} r \bar{\imath} f \grave{\iota} j a m \bar{\imath}$ al-akwān), and that He constitutes the true essence of all concrete things (haqīqat al-ayān), whether living or inanimate beings. .... The reality of their creed (mutaqad) is that the Creator $(\mathrm{T})$ is not something separate from the creation, above the Throne. Rather, in their view the Real manifests in the heavens and the earth, and He manifests in all things with His very essence (bi-dhätihi). ${ }^{29}$

This passage is basically an attempt at defining the term wahdat al-wujüd, the unity of being/existence, a concept for which the Akbarian school is mostly known, and interpreted by its censors as pantheism/monism (ittihāad). AlWāsiți clearly makes no attempt to hide that he is one such censor. After the above description of Akbarian doctrine, he concludes that "when I perceived them in this fashion, my heart turned away from them with intense aversion!"30

Now, in reality, wahdat al-wujüd was never used as a technical term by Ibn 'Arabī nor by al-Qūnawī, both of whom are mentioned in the quoted passage. While some disciples of Ibn 'Arabi may have used it, the first to do so explicitly was probably the Sufi philosopher 'Abd al-Haqq b. Ibrāhīm Ibn Sabīn (d. $669 / 1270$ ). However, it must be noted that Ibn Sab'in was not directly linked to Ibn 'Arabī through any teacher, although he did know al-Qūnawī and became

29 Al-Wāsiṭī, Rihla, p. 40.

$30 \quad$ Ibid. p. 41 . 
the second shaykh of the latter's pupil, al-Tilimsānī. Because he was familiar with Ibn 'Arabī's work and his own doctrine was certainly influenced by it, he may nevertheless be identified as an Akbarian Sufi. ${ }^{31}$ As we shall see below, al-Wāsițī certainly considered him as such.

What both Ibn 'Arabī and al-Qūnawī did discuss in their writings, and which al-Wāsițī was clearly conscious of, is the relation between existence and God's oneness. According to their teachings, true existence only belongs to God, since all things that are not God are dependent on Him for their existence. Existence is thus essentially one because God in His essence (dhāt) is also one. Multiplicity is explained through the reality of the names and attributes by which God has described Himself in His revelation. Ibn 'Arabī held that while God's essential being is completely distinct from the phenomenal world and totally beyond its reach, $\mathrm{He}$ is at the same time manifest in it through the projection of His names and attributes in all that He creates. Thus, while concrete things have no existence in themselves - since that would make them independent of God, which they are not - they receive existence through His names and attributes. This means that they are both identical with existence and other than existence at once. From that perspective, Ibn 'Arabī and al-Qūnawī viewed existence in terms of both affirmation and negation. ${ }^{32}$

Al-Wāsitị could not but conclude that the implications of the language and terminology used by the Akbarians to set forth their understanding of God's unity inevitably leads to monism. And because he believed monism to be in contradiction with the very essence of Islam, the affirmation of God's absolute unity, it became clear to him that he was dealing with heretics (zanādiqa). An assertion he makes that demonstrates this conclusion is that, according to Akbarian doctrine, "their god is 'existence' (al-wujūd) that permeates dogs, pigs, rats, and dung beetles," but, he responds, "God is too exalted to be like this, separate by His essence and attributes from all He has created." 33 He contends, moreover, that the Akbarian view of divine reality will lead people to abandon the revealed law, because "to them, the sharīa is [merely] a barrier of regulation (siyaj nizām) to keep the world in proper order. For otherwise, who would be the worshipper and who would be worshipped?" ${ }^{34}$ We will delve deeper into his polemics against the doctrine of the Akbarians in chapter 4.

$31 \quad$ William C. Chittick makes this argument in: "A History of the Term Wahdat al-wujūd," in In Search of the Lost Heart: Explorations in Islamic Thought, ed. Mohammed Rustom, Atif Khalil, and Kazuyo Murata (Albany: State University of New York Press, 2012), p. 81. Chittick gives an excellent overview of the doctrine of Ibn 'Arabī and al-Qūnawī in: "A History of the Term Wahdat al-wujūd," pp. 75-79.

33 Al-Wāsițī, Riḥla, p. 40.

34 Ibid. p. 41. 
For our current purpose it is relevant to add that he appears to have recognized a relationship between monistic teachings and the cultural background of the shaykhs who formulated them. In Talqīh al-afhām he has an interesting remark in that regard when he refers to monists as "those who follow the wicked creed of the people from al-maghrib and al-rūm." ${ }^{35}$ By 'al-maghrib' he means the Islamic west, which includes al-Andalus and North Africa, and by 'al-rüm' he means the Islamic east, in particular Anatolia and perhaps Persianspeaking areas in general. This cultural background is indeed historically related to the individuals he mentions by name in his writings as the leaders of the ittihädiyya. Those with a western background among the names he mentions are the shaykh al-akbar himself, Ibn Sabiinn, the latter's pupil Ibn Hūd, and al-Tilimsānī. ${ }^{36}$ Those with an eastern background among the names he mentions are al-Qūnawī, Yūnus b. Yūsuf (or Yūnus) b. Musāid al-Shaybānī (d. 619/1222), and the rather obscure figure of Awḥad al-Dīn 'Abd Allāh al-Balyānī (d. 686/1288). ${ }^{37}$ If there was indeed a certain relationship between doctrine and the cultural background of these shaykhs, we may ask how, as al-Wāsitịi claims, they were able to reach a degree of success in the convents of Cairo.

Before we further elaborate on this topic, it is necessary to examine the history of Ibn 'Arabī's school in Cairo prior to al-Wāsițî̀'s arrival there so we can judge the extent to which they were indeed able to earn a notable place among the city's Sufis. We know that followers of Ibn 'Arabī were already present in Cairo several decades earlier. They appear to have experienced varying degrees of success in establishing themselves in the city's religious landscape. Ibn 'Arabī visited Cairo twice during his lifetime and had stayed in the Sa'îd alsu'adā at least during his first stay. It is unclear, however, to what extent something of an Akbarian circle remained after he left. ${ }^{38}$ The first real establishment

35 Al-Wāsițī, Talqūh al-afhām, p. $15^{2}$.

36 Ibn 'Arabī, Ibn Sab'īn, and Ibn Hūd came from al-Andalus; for Ibn Hūd, cf. al-Ṣafadī, A'yān al-'așr, vol. 2, p. 202. It is unclear whether al-Tilimsānī was born in Tlemcen or in Damascus. He descended from the Berber tribe Kūmiya, which is based near Tlemcen, cf. Fritz Krenkow, "Al-Tilimsānī," in $E I^{2}$ : vol. 10, p. 500.

37 Al-Qūnawī came from Konya, Turkey. Al-Shaybānī came from al-Qunayya near Mardin, Turkey. According to al-Dhahabī, the latter was a "mad" (majdhūb) shaykh who had no real knowledge and whose poetry contains monism (ittihâd), cf. Tärīkh, vol. 44, pp. 471473. See also: Trimingham, The Sufi Orders, p. 15. Al-Balyāni came from Shiraz, Iran, and is noted by Chittick as a member of the Akbarian school, cf. "The school of Ibn 'Arabī," p. 519. For the instances where al-Wāsițī presents us with the names of the above mentioned Akbarian shaykhs, see his: Risālatuhu ilā al-shaykh Ahmmad al-Maghrib̄̄, p. 113, where he refer to al-Qūnawī as "al-Rūmī"; 'Umdat al-țullāb, p. 214; al-Tadhkira wa-al-ítibār, p. 34 .

38 Ibn 'Arabī's first visit to Egypt was in 598/1202 and his second in 6o3/1207, cf. Addas, Quest for the Red Sulphur, pp. 196 and 302-305. 
of Akbarian Sufis in the Egyptian capital probably occurred under his disciple al-Qūnawī, who settled there in 643/1245, some five years after his master's passing. As someone who understood Ibn 'Arabī like no other and who had been granted ijāzas in all of his major works, al-Qūnawīs coming to Cairo would have contributed greatly to the spread of his shaykh's teachings there. ${ }^{39}$ And apart from Mu’ayyad al-Dīn al-Jandī (d. 70o/130o), all of al-Qūnawì's major disciples who would one day become important transmitters of the Akbarian school in their own right were also with him when he lived in Cairo. ${ }^{40}$ His most renowned pupil and close friend al-Tilimsānī resided in the Sacìd alsu'adā at that time..$^{41}$ Other important Akbarians who studied under al-Qūnawī in Cairo were Sacìd (or Sađd) al-Dīn Muḥammad al-Kāsānī al-Farghānī (d. 699/1300), ${ }^{42}$ the above-mentioned Shams al-Dīn Muhammad al-Aykī (or al-Īkī) (d. 697/1298),43 and Fakhr al-Dīn Ibrāhīm b. Buzurgmihr al-'Trāqī (d. 688/1289), ${ }^{44}$ all of whom, we may observe, were of Persian origin. Although it is unknown when exactly al-Qūnawī and his disciples left Cairo, we do know that he was back in Konya by $652 / 1254.45$

The time these representatives of Ibn 'Arabī's school spent in Cairo would undoubtedly have left something of a mark on the city's Sufi community. In all likelihood, it signified the starting point from where the Akbarian movement was able to slowly flourish in Egypt's capital, to eventually achieve what alWāsitị has described to us as a notable presence in several of its convents before the turn of the century. That this was indeed the case is best exemplified by the case of al-Aykī, who we have seen became Egypt's shaykh al-shuyūkh in 684/1285. This formally made him head of all Sufis in the Mamluk domains and put him in charge of not only the Sa'ìd al-su'adā', but also the al-Fayyūm

39 Richard Todd, The SufiDoctrine of Man:Șadral-Dīnal-Qūnawı̈’ Metaphysical Anthropology (Leiden: Brill, 2014), p. 2o. On al-Qūnawī’s ijāzas, see: Gerald Elmore, "Ṣadr al-Dīn alQūnawì's Personal Study-List of Books by Ibn al-'Arabī, JNES, vol. 56, No. 3 (Jul., 1997): pp. $161-181$.

40 Al-Jandī was initiated by al-Qūnawī in Konya at a later stage in the latter's career, cf. alJāmī, Nafahăt al-uns, vol. 2, p. 739, and: Todd, The Sufi Doctrine, pp. 23-25.

41 Al-Ṣafadī, al-Wäfi, vol. 15, p. 250, and: Todd, The Sufi Doctrine, p. 17.

42 Ibn al-'Imād, Shadharāt, vol. 7, pp. 782-783; Al-Ṣafadī, al-Wäfì, vol. 2, p. 99; Todd, The Sufi Doctrine, p. 19.

43 Ibn al-Imād, Shadharāt, vol. 7, p. 767; al-Ṣafadī, Áyān al-'așr, vol. 4, pp. 351-353; Taqī alDīn Aḥmad b. 'Alī al-Maqrīzī, Kitāb al-muqaffā al-kabīr, ed. Muḥammad al-Ya'lāwī (Beirut: Dār al-gharb al-islāmī, 1991), vol. 5, pp. 447. Acording to al-Jāmī, al-Aykī belonged to the elite (khawāṣṣ) of al-Qūnawī's followers, cf. Nafahăt al-uns, vol. 2, p. 629.

44 William C. Chittick, "Erāqī, Faknr-al-Dīn Ebrāhīm," EIr, vol. viıI, Fasc. 5, pp. 538-540.

45 Todd, The Sufi Doctrine, p. 2 o. 
khānqāh and the al-Mashțūb khānqāh. ${ }^{46}$ As previously noted, he was able to get this position thanks to his friendly relations with the controversial amir alShujāīì.

Besides Cairo's most important khānqāh run by the sultanate, there were at least two more convents that housed Sufis who were labelled monists by alWāsitị. The first of these is the convent of the Yūnusiyya, the Sufi țăifa of the earlier-mentioned Yūnus al-Shaybānī, which was located at Bāb al-Lūq in the city's southeast. ${ }^{47}$ Al-Wāsiți mentions the Yūnusiyya in relation to the ittihàdiyya at least twice in his writings, indicating that he must have been exposed to followers of shaykh Yūnus. The second convent is that of the shaykh Abū al-Fatḥ Naṣr b. Sulaymān al-Manbijī (d. 719/1319), who would later turn out to become one of Ibn Taymiyya's most fierce opponents from among the Sufis. According to al-Maqrīīi, himself by no means fond of the Akbarians, al-Manbijī would go too far in his love for Ibn 'Arabī. The shaykh's zäwiya was located at Bāb al-Nașr in the city's northeast, not far away from the Sa'īd al-su'adā'. ${ }^{48} \mathrm{Al}$ though no mention is made of the date it was established, given the fact that al-Manbijī would already have been a shaykh in his fifties when al-Wāsițī was in Cairo, it is certainly possible that it was open and running at that time. ${ }^{49}$ There is also a remote hint at a possible link between al-Manbijī and al-Wāsițī in a letter Ibn Taymiyya sent to the Cairene Sufi shaykh in $704 / 1304 \cdot{ }^{50} \mathrm{In}$ it Ibn Taymiyya actually mentions al-Wāsițī, referring to him only as "our master shaykh 'Imād al-Dīn," which suggests that he expected al-Manbiji to know of whom he was speaking. ${ }^{51}$ If that was indeed the case, then the two would surely have made each other's acquaintance in Cairo.

Of course, Sufis with Akbarian leanings did not merely occupy the above convents, but also used them as platforms to disseminate their own teachings. This is attested to by al-Wāsiți’s autobiography in the section on the Akbarians he met in Cairo, where he implies that it was in the convents that he was exposed to their writings for the first time. We are told that it was only when he learned about the contents of Ibn 'Arabī's Fuṣuṣ al-hikam that he became fully convinced of the heretical nature of their doctrine: "This clarified their school

46 According to his document of investiture (taqlīd), preserved in by Nāșir al-Dīn Muhammad b. 'Abd al-Rahīm Ibn al-Furāt, Tärīkh Ibn al-Furāt, volume 8, ed. Qusțanținn Zurayq (Beirut: al-Mațba'a al-amīrkāniyya, 1939), p. 31; see also: Fernandes, The Evolution, p. 52. Al-Maqrizi, al-Mawā'iz, vol. 4, pp. 314-315.

48 Al-Maqrizi, al-Mawāi iz, vol. 4, p. 310.

49 Al-Manbijī was born in 638/1241 and died in 719/1319, cf. Ibn Taghrī Birdī, al-Nujūm alzāhira, vol. 9, pp. 244-245.

50 Taqī al-Dīn Aḥmad Ibn Taymiyya, Majmūáat al-rasā̉il wa-l-masā̉il, ed. Muhammad Rashīd Riḍā (Cairo: Lajnat al-turāth al-'arabī, 1976), vol. 1, p. 161. Ibid. vol. 1, p. 170. 
(madhhab) [for me], so that I came to know the true nature of their objectives. I subsequently became weary of them for a long time." ${ }^{52}$ In all likelihood he was exposed to several more titles by Akbarian Sufis in Cairo, such as Ibn 'Arabī's magnum opus, al-Futūhāt al-makkiyya, his al-Amr al-muhkam almarbüt, Ibn Sab'īn's Budd al-ārif, and al-Qūnawī's Kitāb al-fukūk, all of which he mentions in other writings where he discusses their doctrine. ${ }^{53}$

Besides these titles, we know for sure that the Sufi poetry of Sharaf al-Dinn 'Umar Ibn al-Fāriḍ (d. 632/1235) was taught by Akbarians in the convents of Cairo. His Nazm al-sulük, a didactic poem on the spiritual way, was particularly popular among them. It is in fact due to their frequent use of this poem that its author was in a sense claimed by them as a member of their school. ${ }^{54}$ This trend started with al-Qūnawī, who greatly admired Ibn al-Fāriḍ and gave discourses on the poem in Persian when he was in Cairo. ${ }^{55}$ Al-Ayki, too, was greatly fond of Ibn al-Fāriḍ's poetry, especially the Nazm al-sulük, which he is known to have often recited and propagated among the Sufis of Cairo. ${ }^{56}$ Several notable early Akbarians also composed commentaries on it. The first of these were by two of al-Qūnawīs students, al-Tilimsānī and al-Farghānī. The latter actually wrote one in Persian, Mashāriq al-darārī, and one in Arabic, Muntahä al-madārik, which were reportedly taught in Cairo in $670 / 1271 .{ }^{57}$ This tells us that the Nazm al-sulük not only continued to be a celebrated poem within the Akbarian school from al-Qūnawī onwards, but that it was also

53 These titles are not mentioned in the Rị̣la but in three other of al-Wāsitịis treatises: Qāंida fi al-farq bayna mushāhadat al-qayyūmiyya wa-al-tahaqquq bihā, pp. 265-266, Bāshūrat al-nușūṣ, p. 31, and: Risālatuhu ilā al-shaykh Aḥmad al-Maghribū, p. 113.

Th. Emil. Homerin, who has done much work on Ibn al-Fāriḍ's poetry, has noted this as well in his book From Arab Poet to Muslim Saint: Ibn al-Fārid, His Verse, and His Shrine (Cairo, Egypt: American University in Cairo Press, 2001), pp. 28-30. Al-Jāmī, Nafahăt al-uns, vol. 2, p. 721; Todd, The Sufi Doctrine, p. 19.

56 Homerin, From Arab Poet, p. 40. See also: al-'Aynī, Iqd al-jumān, vol. 3, p. 179, where it is related that al-Aykī recited particular verses of Ibn al-Fāriḍ, which are in fact from the Nazm al-sulūk, as found in: Sharaf al-Dīn 'Umar b. 'Alī Ibn al-Fāriḍ, Dīwān Ibn al-Fārị̣ (Beirut: Dār Șādir, 1962), p. 73.

Al-Ṣafadī, al-Wäfì, vol. 2, p. 99. On these commentaries, see: Giuseppe Scattolin, "The Key Concepts of al-Farghānī's Commentary on Ibn al-Fāriḍ's Sufi Poem, al-Tā’iyyat al-Kubrā," JMIAS 39 (2006): pp. 33-83; also: Chittick, "The school of Ibn 'Arabī," p. 512. From the following generation of Akbarians there is a commentary by Kamāl al-Dīn 'Abd al-Razzāq al-Kāshānī (or Qāshānī) (d. 73o/133o), a disciple of al-Jandī mentioned earlier as a member of al-Qūnawī's inner-circle. Al-Kāshānī's most eminent pupil, Sharaf al-Din Dāwūd al-Qayṣarī (d. 751/1350), also joined the list of commentators with his Sharh tā’iyyat al-sulūk; see: Mușțafā b. 'Abd Allāh Hājjī Khalīfa, Kashf al-žunūn 'an asāmī alkutub wa-al-funūn (Baghdad: Maktabat al-muthannā, 1941), vol. 1, p. 266. 
continuously assigned a practical function by its adherents, in the sense that it was used as a base text from which to expound upon the Sufi way.

It is thus not unthinkable that it was in these convents that al-Wāsiți himself was exposed to Ibn al-Fāriḍ's poetry. Although he never mentions the Sufi poet by name, on two separate occasions he presents us with an anonymous citation of verses by his hand, one of which actually comes from the Nazm alsulūk. ${ }^{58}$

In spite of their influence in the convents, Sufis with Akbarian leanings were not on the whole without controversy in Cairo. According to Alexander Knysh, who extensively studied the history of the polemics against Ibn 'Arabī, the earliest condemnation of the shaykh al-akbar came from Ibn 'Abd al-Salām upon his arrival in Cairo in 639/1241. ${ }^{59}$ Knysh's second most notable example of an anti-Akbarian scholar who settled in Cairo is Quṭb al-Dīn (Ibn) al-Qasțallānī (d. 686/1287). ${ }^{60}$ The latter already recognized the ittihaddiyya as a distinct Sufi țāifa whose interpretation of Sufism he considered heretical. Al-Ṣafadì makes note of this in his biographical dictionary, saying that al-Qasțallānī "wrote against the [Sufi] group (tă $i f a)$ whose way was followed by Ibn Sabinn, which was started by al-Ḥallāj and closed by al-'Afïf al-Tilimsānī." ${ }^{\prime 1}$ Al-Qasțallānī's polemics against the Akbarians later influenced Abu Ḥayyān al-Gharnați (d. 745/1344), who quotes his predecessor in that regard in his well-known commentary on the Qur'an. ${ }^{62}$ Furthermore, the same Abū Hayyān shared his hostile attitude towards the Akbarian shaykh al-Aykī with Taqì al-Dīn 'Abd

$5^{8} \quad$ Al-Wāsițī cites Ibn al-Fāriḍ's poem 'Qalbī yuhaddithunì in his Qawā'id al-nubuwwāt: Qā'ida nabawiyya, p. 301. The lines he cites can be found in: Ibn al-Fāriḍ, Dīwān, on separate pages, namely, pp. $15^{1}$ and ${ }_{152}$. For the quote from the Nazm al-sulūk, see al-Wāsițī's Qã ida fí al-ḥubb fí Allāh haqüqat ${ }^{a n}$, p. 54. The lines he cites can be found in: Ibn al-Fāriḍ, Dīwān, p. 51 .

59 Knysh, Ibn 'Arabi in the Later Islamic Tradition, pp. 61-85. I will only mention the scholars that are relevant to the Cairene context here. There were, however, several other scholars in the century we are dealing with who attacked Akbarian Sufis. Besides Knysh's book, a few more names he makes no mention of can be found in the study of Daghash b. Shabīb al-Ajmī, although this work should be used with caution due to its polemical nature: see: Ibn 'Arabī: 'Aqüdatuhu wa-mawqif 'ulamā' al-muslimīn minhu. Min al-qarn al-sādis ilā alqarn al-thälith 'ashr (Kuwait: Maktabat ahl al-athar, 2011), in particular pp. 255-273, where names of scholars from the seventh/thirteenth century are listed.

6o Knysh, Ibn 'Arabi, pp. 44-45, 169, and 359n2. At one point in his life al-Qasțallānī became the head of the Dār al-Ḥadīth al-Kāmiliyya in Cairo, cf. Subki, Țabaqat al-shāfíiyya, vol. 6, p. 44.

61 Șafadī, al-Wāfì, vol. 2, p. 95. See also: al-Yāficì, Mir’āt, vol. 4, p. 129.

62 Abū Ḥayyān Muhammad b. Yūsuf al-Andalusī, al-Baḥr al-muhīt fì al-tafsīr, ed. Șidqī Muḥammad Jamīl (Beirut: Dār al-fikr, 1992), vol. 4, p. 210, and vol. 5, p. 404; also mentioned by Hofer, The Popularisation of Sufism, p. 66 . 
al-Raḥmān Ibn Bint al-A'azz (d. 695/1296), the vizier of Sultan Qalāwūn. But while Abū Hayyān only expressed this in writing, Ibn Bint al-A'azz took it a considerable step further and made sure that al-Ayki got dismissed from the post of shaykh al-shuyūkh. ${ }^{63}$ Another Sufi who got in trouble in Cairo for his supposed monistic teachings was Ibn Sabinn. He had reportedly fallen into the disfavor of Sultan Baybars I, who was notified of his disputed Suf teachings. The shaykh eventually left the city as he was unable to find peace there. ${ }^{64}$ These examples show that those individuals whom al-Wāsiți labelled monists did at times experience opposition over the course of the seventh/thirteenth century in Cairo, which tells us that their Sufi doctrine was not necessarily considered mainstream there.

Nevertheless, it would be an exaggeration to say that the city was a particularly hostile environment for them when al-Wāsiți visited it. The tradition of heresiography against Akbarian Sufism really only took off in the early eighth/ fourteenth with Ibn Taymiyya, who is generally considered the first to formulate a coherent polemical strategy that proved effective. ${ }^{65}$ And even then, it was Damascus in particular where the Akbarians and those close to them in doctrine were looked upon with suspicion. Cairo remained much more open to Ibn 'Arabī and his ilk. ${ }^{66}$

Having said that, we may now return to our initial question: How were the Sufis with Akbarian leanings able to reach a degree of success in the convents of Cairo? In his conviction that their heresy was decidedly evident, this appears to have been a question that bothered al-Wāsiți as well. An answer is perhaps found in the cultural sphere. We may note that the Turco-Persian context seemed to have been much more open to Akbarian doctrine than the Arab context. This would certainly explain why, as Claude Addas has shown, the

63 Some sources relate that this came to pass because al-Aykī did not grant Ibn Bint al-A'azz the customary honor of standing up when the vizier visited the Sa'īd al-su'adā'. Al-'Aynī, on the other hand, reveals that the dispute between the two was rooted in al-Aykīs love for the poetry of Ibn al-Fāriḍ, see: Ibn al-Furāt, Tārīkh Ibn al-Furāt, p. 124; al-Maqrizi, Kitāa al-Muqaffā, vol. 5, p. 447; al-'Aynī, Iqd al-jumān, vol. 3, p. 179; on this episode, see also: Hofer, The Popularisation of Sufism, pp. 65-66.

64 Al-Sha'rānī, al-Tabaqāt al-kubrā, vol. 1, p. 35; Faure, Adolph. "Ibn Sabīn," in $E I^{2}$ : vol. 3, pp. 921.

65 Cf. Michel Chodkiewicz, "Le procès posthume d'Ibn 'Arabī," in Islamic Mysticism Contested: Thirteen Centuries of Controversies and Polemics, ed. Frederick de Jong \& Bernd Radtke (Leiden, Netherlands: Brill, 1999), pp. 98-99. Also the observation of Th. Emil Homerin, "Sufis and their Detractors in Mamluk Egypt," in: Islamic Mysticism Contested: Thirteen Centuries of Controversies and Polemics, ed Frederick de Jong \& Bernd Radtke (Leiden, Netherlands: Brill, 1999), p. 234.

66 Geoffroy, Le Soufisme, p. 459. 
students of al-Qūnawī were especially successful in spreading their school of Sufism in Turkey and Iran.$^{67}$ Now, when it comes to Cairo, we saw in the previous section on the Sufis of convention that the Saìd al-su'adā' was dominated by Persians from the east, which was in fact more or less the situation in all the Cairene khānqāhs sponsored by the sultanate. ${ }^{68}$ This presence of Persian immigrants is undoubtedly why al-Qūnawī gave classes on Ibn al-Fāriḍ's Nazm al-sulük in Persian rather than in Arabic when he lived in the Egyptian capital. So even though seventh-/thirteenth-century Cairo was not necessarily sympathetic towards the Akbarians as we have seen, I would argue that their doctrine was likely much more easily accepted as normative in the context of the city's "state-sponsored" convents due to the distinct presence of Sufis with a Persian background. Needless to say, the current study alone is not enough to confirm this hypothesis as a historical fact. Further inquiry is certainly needed.

As for al-Wāsițī, his conclusions regarding the Akbarians he met in Cairo was a serious setback in his search for the pathway to God, leading him to conclude that he had thus far only benefited from two groups. The first were the Shāfi'i jurists, from whom he learned God's commandments and prohibitions. The second were the Alexandrian Sufis, the Shādhiliyya, from whom he learned the goal of the spiritual journey (al-mațiub), the properties of servitude (a hkām $a l$ - ubüdiyya), and the marks of the different states and stations that the seeker attains along the spiritual path. Thus, he says, the way of the jurists became like his physical form (al-qālab al-jismì), and the way of the Shādhilīs became like his inward spirit $(a l-r u ̄ h) .{ }^{69}$

But I remained like a destitute who has attained the first of degrees (darajāt) while the highest of them is visible to him, so that he is in need of the degree that is in between them. At that point I was nevertheless satisfied with this, for it stilled my heart's hunger - surely, the starved person will be nourished by anything there is $!^{70}$

Looking for the last piece of the puzzle, he was perhaps drawn to Damascus by its status as a Hanbalī stronghold. We have seen that he claims to already have had noticeable traditionalist leanings in Alexandria. It was indeed Damascus where he found what he believed to be the final ingredient to perfect his vision of Sufism.

\footnotetext{
67 Addas, Quest for the Red Sulphur, p. 233.

68 Geoffroy, Le Soufisme, p. 168.

69 Al-Wāsițī draws the same conclusion on two occasions in his autobiography, cf. Rihla, pp. $35^{-36}$ and 44 . 
Al-Wāsițī arrived in Damascus towards the end of the seventh/thirteenth century. Before he became a follower of Ibn Taymiyya, he may have made one final attempt at attaching himself to a Sufi shaykh when he asked the Sufi Ibn Hūd to guide him on the spiritual way. However, this could very well have been motivated by a desire to expose him as a fraud. ${ }^{71}$ Either way, as he joined the city's traditionalist community al-Wāsiți would soon enter Ibn Taymiyya's circle and become convinced that, as the only group that truly followed the way of the Salaf in belief and practice, they were the saved sect of Islam.

The remainder of the current chapter will follow this last step of his journey in the city where he spent his final years. It is divided into three sections. The first of these will focus on context and provide background to the traditionalist community of Damascus and the role of Sufism in it. Here we will also briefly discuss Ibn Taymiyya's often-mentioned supposed link with Qādirī Sufism. The second section will provide a study of al-Wāsițīs account of the early years he spent among Ibn Taymiyya's circle. In the final section we will elaborate upon al-Wāsițìs own position as a Sufi shaykh in relation to Ibn Taymiyya and the members of his inner circle, and what can be said about how they operated as a group in early eighth-/fourteenth-century Damascus.

\subsection{Sufism and Hanbalì Piety in Damascus}

The Hanābila experienced their heyday in Baghdad, the city of their eponymous founder Ahmad Ibn Hanbal (d. 241/855). Here they became especially notorious during the fourth/tenth and fifth/eleventh century due to their activist stance in publically commanding right and forbidding wrong. Hanbali mobs would go around Baghdad to harass wine sellers, brothels, musicians, or any other activities they considered to be in contradiction with proper religious morality. At times they could even afford to openly criticize and confront the powers that be. They were partially able to get away with this thanks to

$71 \quad$ Al-Dhahabī relates that al-Wāsițī described his meeting with Ibn Hūd as follows: "I went to him and asked him: 'I want you to guide me along the spiritual way (tusallikunī),', to which he replied: 'By which of the paths do you wish to travel; by that of Moses, that of Jesus, or that of Muhammad?' - and he meant that every religion leads to God!" cf. alDhahabī, Tārīkh, vol. 52, p. 401, and: Ibn al-'Imād, Shadharāt, vol. 7, p. 780. It is worth mentioning in this regard that Ibn Hūd was known as a controversial figure in Damascus, in part because he had many Jews among his disciples with whom he apparently studied Maimonides. If al-Wāsițī was aware of this, it could be that he simply wanted to see how Ibn Hūd would respond to his question. On Ibn Hūd's relation to Jews, see for instance: Joel L. Kraemer, "The Andalusian Mystic Ibn Hūd and the Conversion of the Jews," in Israel Oriental Studies XII (1992): pp. 59-73. 
their popularity among the city's populace. But as Hanbali scholars became closer connected to the authorities with the passing of time, accepting positions that they had hitherto denied out of piety, their activism started to decline. By the time the 'Abbāsid caliphs became autonomous again in the sixth/ twelfth century - having previously operated under Būyid and Seljūq rule respectively - Hanbali activism had been permanently replaced by quietism under the patronage of government officials. ${ }^{72}$ As noted in chapter 1, after Baghdad had fallen to the Ilkhanids, the Hanbalīs were unable to retain their position. Therefore, al-Wāsițī will probably not have found a strong Hanbalī center when he visited the city.

It was only when he migrated to Damascus that he found what had by then become the capital of the Hanbalī school in his age. But as a city dominated by Shāficiss, most of whom were Ash'arī in theology, Damascus never provided the security of official protection that the Hanbalis had once enjoyed in Baghdad. ${ }^{73}$ They nevertheless managed to grow quite powerful there. By the end of the seventh/thirteenth century the Hanbalīs came to dominate certain quarters of Damascus, organized around the leadership of notable Hanbali families and their shaykhs. In these quarters they were able to finance the construction and management of their own mosques and madrasas independently of the Ayyubid, and thereafter Mamluk, sultanate. ${ }^{74}$ It was their influence in Damascus in this epoch which ensured that the mastership of hadith switched to Greater Syria after having been based in Iraq for practically all previous centuries. ${ }^{75}$

It will be useful to have a closer look at the overall course of this development, in order to get a clearer image of the context of Damascene Hanbalism as al-Wāsițī encountered it. The first influential Hanbalī family, the Banū alHanbalī, entered Damascus somewhere by the end of the fifth/eleventh century. In the century that followed, Hanbali activity intensified rapidly. The Banū al-Hanbalī opened the first school dedicated solely to their madhhab, al-Madrasa al-Hanbaliyya al-Sharifiyya, located within the confinements of the city walls. Not long after the Banū al-Munajjā, another Hianbalì family, which had established itself in the old city, set up a second madrasa by the

72 Michael Cook, Commanding Right and Forbidding Wrong in Islamic Thought (Cambridge: Cambridge University Press, 200o), see chapter 6 for a detailed study of this development.

73 Laoust, "Le Hanbalisme," p. 128; Cook, Commanding the Right, pp. 146-147.

74 Ira M. Lapidus, Muslim Cities in the Later Middle Ages (Cambridge: Harvard University Press, 1967), p. 86, and: Joan E. Gilbert, "Institutionalization of Muslim Scholarship and Professionalization of the 'Ulamā' in Medieval Damascus," Studia Islamica, No. 52, (1980): p. 130.

75 Scott C. Lucas, Constructive Critics, Hadith Literature, and the Articulation of Sunnī Islam: The Legacy of the Generation of Ibn Sa'd, Ibn Main, and Ibn Hanbal (Leiden: Brill, 2004), p. 109, and also: Pouzet, Damas au viIe-XIIIe siècle, p. 85. 
name of al-Mismāriyya. In the same age a third Hanbali family, the Palestinian Maqdisīs of the Banū Qudāma, emigrated to Damascus to flee from Crusader invaders. They soon dominated the Damascene suburb on the slopes of Mount Qāsyūn, which was subsequently dubbed 'al-Ṣalihịyya' after the mosque of Abū Șālih where the Qudāma family had lived when they first arrived in the capital of Shām. ${ }^{76}$ By the end of the sixth/twelfth century they managed to open the Hanbalī cathedral mosque al-Jāmi' al-Muzaffarī and the 'Umariyya madrasa. Over the course of the next century they founded two more madrasas - both named al-Diyā̉iyya - and took over the Șāhibiyya madrasa and the Dār al-Hadīth al-Ashrafiyya al-Barrāniyya, all located in the Ṣalihịiyya suburb. ${ }^{77}$

The Hanbali expansion continued with two other families that settled in Damascus. In the middle of the seventh/twelfth century many Hanbalis from Harrān, a city in present-day Turkey, were seeking safety in Damascus from the Ilkhanid advance in their homeland. Among them the most notable were the Banū Taymiyya, who arrived in 667/1269 under the leadership of the shaykh of Harrān, Shihāb al-Dīn 'Abd al-Halīm (d. 682/1284), the father of Ibn Taymiyya. Shihāb al-Dīn and his family ended up in the Qaș̣āâin quarter of the old city near the western gate, Bāb al-Jābiyya, where they took up residence in the Dār al-Hadith al-Sukkariyya, over which the shaykh had acquired directorship (mashyakha). ${ }^{78}$ Last is the Banū al-Jawzī, the family of the well-known Baghdadi scholar Abū al-Faraj 'Abd al-Raḥmān Ibn al-Jawzī (d. 597/1201). In 63o/1233 a son of the latter founded the Jawziyya madrasa south of the Umayyad Mosque, which often served as the seat of the Hanbali judge ( $q \bar{a} d \bar{\imath})$ for the old city. ${ }^{79}$ Needless to say, al-Wāsițī would have found Damascus to be a place with plenty of opportunities for a traditionalist seeker of knowledge, both in the old city and in al-Ṣâliḥiyya. ${ }^{80}$

But what did Damascus have to offer in terms of Sufism for a traditionalist? There are some elements that may be viewed as characteristic of Damascene spirituality in al-Wāsiți’s context that would surely have appealed to him. As we remarked in the previous section, Damascus was not as open to Ibn 'Arabī's school as Cairo. We find, for instance, that by the eighth/fourteenth century Ibn 'Arabī's grave - located in the Hanbalī suburb of al-Ṣâlihịya - had turned

76 Stefan Leder, "Charismatic Scripturalism: The Ḥanbalī Maqdisīs of Damascus," Der Islam, volume 74, Issue 2 (Jan 1997): p. 283.

77 Pouzet, Damas, pp. 81-83.

78 'Abd al-Q̄ādir b. Muhammad al-Nu'aymi al-Dimashqī, al-Dāris fìt tārīkh al-madāris (Beirut: Dār al-kutub al-'ilmiyya, 1990), vol. 1, p. $5_{6}^{6 .}$

79 Pouzet, Damas, pp. 83-85.

$80 \quad$ For a map with the locations of the abovementioned mosques and madrasas, see p. 167 . 
into something of a garbage dump. ${ }^{81}$ While certainly not hostile to tașawwuf itself, it may be that the strong presence of the traditionalist camp in the city also had its effect on the trends of spirituality that were able to thrive there. That is not to say that Damascus was void of Sufis with Akbarian leanings or who displayed ecstatic behavior. There certainly were fractions of Akbarians there at the time of al-Wāsițīs arrival, the most vibrant of which was perhaps Ibn Sab'īn's Sab'inniyya, by then under the leadership of Ibn Hūd. Other examples of Sufi țäifas that were occasionally regarded with distrust by the city's Sunni jurists were the aforementioned Yūnusiyya, the Rifăciyya, their sub-fraction the Hariiriyya, and a group that was referred to as 'those captivated by God,' al-muwallahün. As opposed to the former groups, the muwallahūn were mainly attacked for their practices rather than their theological beliefs, and in most cases this had to do with their disregard for ritual purity..$^{82}$ Again, it was not that such groups were systematically opposed, but we do find that they were not quite as popular in Damascus as they were in other places of the Muslim world. It thus seems that al-Wāsiți’s journey had finally taken him to a land where the local religiosity was possibly more in line with his own preferences than what he had witnessed in Iraq and Egypt. ${ }^{83}$

Popular in Damascus was the moralistic, ascetic spirituality of the Hanbaliss, referred to in most cases as zuhd (renunciation) rather than tașawwuf. Indeed, in biographical dictionaries from around the era that concerns us we hardly find the label 'șūfi being attached to Hanbalī authorities. There are, however, numerous cases where 'zāhid' (renunciant, pl. $z u h h \bar{a} d$ ) is used instead. A wellknown example is the Hanbalī scholar al-Jīlānī, who undoubtedly viewed himself as a Sufi, but is nevertheless labelled a $z \bar{a}$ hid instead of a Sufi by Ibn Rajab. ${ }^{84}$ George Makdisi has therefore opted that these two terms were possibly used interchangeably. ${ }^{85}$ The reality is that it remains very difficult to say how the zuhd-practicing Hanbalīs of Mamluk Damascus would have felt if someone described them as Sufis. There is probably truth in Geoffroy's suggestion that the Hanbalīs' strict rejection of innovation (bid'a) may have made them wary of an epithet that was being widely used by individuals they thoroughly dis-

\footnotetext{
$81 \quad$ Geoffroy, Le Soufisme, p. 459.

82 Pouzet, Damas, pp. 216-226, and 227-230.

83 Geoffroy also notes that the saintly hierarchy inherent to the more ecstatic currents of Sufism was far more prominent and important in Egypt than in Syria, which leads him to conclude that "the ecstatic Syrians unquestionably had a lesser role in society," cf. Le Soufisme, p. 138 .

84 Ibn Rajab, Dhayl, vol. 2, p. 188. That al-Jīlānī occupied himself with Sufism is first and foremost attested to by the sections on tașawwuf found in his al-Ghunya, pp. 269-336.

85 Makdisi, "The Hanbali School and Sufism," p. 63.
} 
agreed with. He hypothesizes that the close relationship between zuhd and Hanbalism may even have been a Syrian specificity. ${ }^{86}$ Whatever the case may be, it cannot be denied that in seventh-/thirteenth-century Damascus the scrupulous observance of zuhd as practiced by many Hanbalīs was commonly viewed as the raison d'être for them being able to perform the kind of miraculous feats - karāmāt - one would expect from Sufi shaykhs.

Al-Ṣālihiyya in particular had grown notorious in this period as home to the line of respected men from the Banū Qudāma, who were widely famed for their extreme piety. In fact, one of the key figures in shaping the Damascene zuhd-tradition was Abū 'Umar Muhammad al-Maqdisī (d. 607/1210). Commonly known as 'the shaykh of the Mountain' (i.e. Mount Qāsyūn), he was popular outside of Hanbalī circles as well. After his passing, his legacy was more or less inherited by his brother, Muwaffaq al-Dīn 'Abd Allāh (d. 620/1223), a respected Hanbalījurist and author of the encyclopedic figh work al-Mughnī.87 Their zuhd consisted of such practices as the consistent performance of supererogatory prayers, especially during the night (i.e. qiyam al-layl, or tahajjud), giving away their worldly possessions to the point of poverty, frequent fasting, and the daily recital of specific portions of the Qur'an. It also included an active commitment to the Muslim community and support during campaigns of holy war (jih $\bar{a} d) .{ }^{88}$ If we are to believe the biographical dictionaries, this kind of piety was indeed the rule among all family members of the Banū Qudāma. It has been argued that, because they were able to combine their traditionalist religious orientation with charismatic leadership, their religiosity quickly became popular in Damascus. ${ }^{89}$ Their public readings of religious texts and tales of pious individuals (akhbār al-șālihīn), attended by people from all classes of society, also contributed to their popularity. Hilyat al-awliy $\bar{a}^{3}$ wa-țabaqāt alasfy $\bar{a}$, the biographical dictionary of the friends of God by the Persian Sufi and hadìth master Abū Nu'aym al-Ișbahānī (d. 430/1038), was likely an important source for them in that regard. ${ }^{90}$ As for their own status as friends of God, this

86 Geoffroy, Le Soufisme, pp. 290-291.

87 Pouzet, Damas, p. 209.

88 For Abū 'Umar, see: Ibn Rajab, Dhayl, vol. 3, pp. 112-119, for Muwaffaq al-Dīn, see: al-Dhahabī, Siyar, vol. 22, p. 167 and: al-'Ulaymī, al-Manhaj al-ahmad, vol. 4, pp. 149-15o. These characteristics were already noted by Leder in his article "Charismatic Scripturalism," in which he connects them to other members of the Banū Qudāma as well.

89 Leder, "Charismatic Scripturalism," p. 303.

$90 \quad$ Leder, "Charismatic Scripturalism," pp. 288-289. Although Abū Nu'aym himself had been in conflict over his beliefs with several of his traditionalist colleagues, it appears that the Hilya became an important and respected work in later traditionalist circles. The Hanbalī hadīth master of Baghdad, Muhammad b. Nāṣir al-Salāmī (d. 550/1155), a contemporary of al-Jīlānī, transmitted it in Baghdad. On al-Salāmī, see: Ibn Rajab, Dhayl, vol. 2, pp. 51-63, 
was enforced not only through their pious deeds performed in public, but also through the composition of their hagiographies, such as those by the family chronicler Diyā' al-Dīn Muḥammad b. 'Abd al-Wāḥid al-Maqdisī (d. 643/1245). The latter recorded the stories of the lives of the Banū Qudāma and the miracles they performed, which served as source material for the later Hanbalī biographer Ibn Rajab. ${ }^{91}$

There was yet another important trend of Hanbalī-linked spirituality present in seventh-/thirteenth-century Damascus that also involved the Banu Qudāma, but whose exact nature is unclear: the influence of 'Abd al-Qādir alJīlānī's Baghdadi Sufism. I have already stressed in chapter 1 that we still understand very little of the development of the early Qādiriyya as a Sufi țăi ifa. While the sources do confirm the existence of an intellectual - and perhaps spiritual - link between al-jīlānī and several Damascene Hanbalīs, we do not know how this manifested itself in practice. There is evidence that the Sufi cloak (khirqa) of the Baghdadi shaykh was being passed on in Greater Syria, but with no clear-cut indication that this went hand in hand with the kind of spiritual master-disciple relationship such as we find among institutionalized Sufi groups of the era. Likewise, biographical dictionaries that deal with our context hardly make mention of the appellation 'Qādirì' as an indication of someone's Sufi affiliation with the țāilfa linked to al-Jīlānī. In light of its relevance to Hanbalī spirituality, we shall briefly elaborate on the lack of clarity surrounding alJīānīs influence in Damascus.

The spiritual link between the Banū Qudāma and al-Jīlanī was first brought to light in George Makdisi's famous article on Ibn Taymiyya's possible affiliation with the Qãdiriyya. Makdisi based himself on three unpublished manuscripts, all of which state that al-Jilānī invested the Maqdisī brothers Abū 'Umar and Muwaffaq al-Dīn with the khirqa, and that both passed it on to the former's son, Shams al-Dīn Ibn Abī 'Umar 'Abd al-Raḥmān (d. 682/1283). It was the latter Ibn Abī 'Umar who allegedly passed it on to Ibn Taymiyya, who in his turn passed it on to his own pupil, Ibn Qayyim al-Jawziyya. It is also claimed in one of the manuscripts that Ibn Taymiyya had once held that al-Jīlānīs țaríqa

and on his transmission of the Hilya: vol. 3, p. 91. Abū 'Umar himself was known to copy the Hilya for the people purely to receive God's blessings, cf. Ibn Rajab, Dhayl, vol. 3, p. 112. Leder, "Charismatic Scripturalism," p. 294. Some of Ḍiyā’ al-Dīn's biographical material on the Banū Qudāma has been studied by Daniella Talmon Heller in "The Shaykh and the Community: Popular Hanbalite Islam in 12th-13th Century Jabal Nablus and Jabal Qasyūn," Studia Islamica, No. 79 (1994): pp. 103-120. For Abū 'Umar's alleged miracles, see for instance: Ibn Rajab, Dhayl, vol. 3, p. 118, and for Muwaffaq al-Dīn, see for instance: al-'Ulaymì, al-Manhaj al-ahmad, vol. 4, pp. 153-154. 
is the greatest of the known brotherhoods. ${ }^{92}$ Even though there is some evidence in support of Makdisi's hypothesis, it still remains highly problematic in view of other primary literature.

First off, according to the relevant biographical sources it was only Muwaffaq al-Dīn who had been a student of al-Jīlānī, and not Abū 'Umar. In 561/116 the former traveled with his cousin, Taqī al-Dīn 'Abd al-Ghanī (d. 6oo/1203), to Baghdad to study under al-Jīlānī, only to spend forty or fifty days with the Hanbali Sufi in his madrasa before he passed away. Perhaps surprisingly, it is related that the two cousins managed to take figh and hadīth from al-jīlānī, with no mention at all of tașawwuf or zuhd.${ }^{93}$ We nevertheless find that three of Muwaffaq al-Dīn's writings on the subjects of good traits ( $\left.f a d \bar{a}^{2} i l\right)$, renunciation (zuhd), and spiritual subtleties (daqāi iq) do contain quotations of traditions that al-jillānī himself had transmitted to him, which may indicate that he did receive something of spiritual instruction from the shaykh. ${ }^{94}$ Besides Muwaffaq al-Dīn's acquaintance with al-Jīlānī, I have come across three instances in two separate sources where he is found in a silsila of the Qādirī khirqa. Out of these three, the two most interesting ones are related by Ibn al-Mulaqqin, who was himself a Qādirī Sufi. ${ }^{95} \mathrm{He}$ relates that Muwaffaq al-Dīn had initiated his own cousin, Shams al-Dīn Muhammad b. Ibrāhīm al-Maqdisī (d. 676/1277), and Taqī al-Dīn Ibrāhīm b. 'Alī al-Wāsițī (d. 692/1293). ${ }^{96}$ Ibn Rajab confirms that this al-Wāsiṭi indeed studied under Muwaffaq al-Dīn and, interestingly, also under Ḍiyā' al-Dīn Mūsā (d. 618/1221), one of al-Jīlānī's sons who had settled in Damascus. ${ }^{97}$ However, he makes no mention of any Sufi affiliation. That there was nevertheless indeed a close bond between al-Wāsițī and Muwaffaq al-Dinn, reminiscent of the Sufi's master-disciple relationship, is attested to by the fact that the former was buried in the latter's mausoleum. ${ }^{98}$ But is this enough to say that Muwaffaq al-Dīn was a Sufi master? The above still leaves us

92 Makdisi, "Ibn Taymīya: A Șūfĩ of the Qādiriyya Order," pp. 123-124.

93 Al-Dhahabī, Siyar, vol. 22, p. 166; al-'Ulaymī, al-Manhaj al-ahmad, vol. 4, p. 54.

94 Cf. al-'Ulaymī, al-Manhaj al-ahmad, vol. 4, p. 155. The works in question are: Kitāb altawwābìn (Beirut: Dār Ibn Ḥazm, 2003), p. 36; al-Mutahābbìn fì Allāh (Damascus: Dār alțibā', 1991), pp. 92 and 41; al-Riqqa wa-al-bukā̉, ed. Muhammad Khayr Ramaḍān Yūsuf (Damascus/Beirut: al-Dār al-shāmiyya, 1994), p. 98.

For the third instance, see: al-'Asqalānī's al-Durar al-Kāmina, vol. 6, p. 25o: here we find that Jamāl al-Dīn Yūsuf al-Mádinī (d. 745/1344), a Ḥanbalī ḥadīth scholar who passed away in Cairo, was invested (albasanī) with the khirqa by one Abū Bakr b. al-'Imād (whom I was unable to identify), who had received it from Muwaffaq al-Dīn, who had received it from al-Jīlānī.

96 Ibn al-Mulaqqin, Țabaqāt al-awliyā', pp. 494-495, and p. 500.

97 Pouzet, Damas, p. 226.

98 Ibn Rajab, Dhayl, vol. 4, pp. 254-266. 
with very little to hold on to and keeps us in the dark as to what the investment of the khirqa - if this was indeed practiced by him - may have actually signified to him.

As for Ibn Taymiyya's investment with the Qādirī khirqa, here too we are left with several obscurities. The first of these concerns the person who is said to have initiated him, Ibn Abī 'Umar. Apart from the fact that Ibn Abī 'Umar's uncle Muwaffaq al-Dīn is mentioned as one of his teachers, I have not found anything that points to his affiliation with any silsila. He is simply described by Ibn Rajab as a $z \bar{a} h i d$, along with many other characteristic elements of piety found in the biographies of members of the Banū Qudāma. ${ }^{99}$ What is certain is that he was one of Ibn Taymiyya's shaykhs, and that the latter held him in high esteem. ${ }^{100}$ Furthermore, Ibn Taymiyya also clearly had an immense respect for al-Jīlānī, both as an authority in the Hanbalī madhhab and as one of the greatest shaykhs among the later Sufis. ${ }^{101}$ When we look at his juridical opinion regarding the bestowal of the khirqa, Ibn Taymiyya held that it should not be seen as an act of the Prophetic Sunna, as there is no foundation in the Islamic texts that supports it, and the different chains of transmission that trace back khirqas to the Prophet's Companions are all false. Even so, he still considered it to fall under the category of permissible acts (mubāhāt) that can be regarded as good (hasan), provided that it is done with a sound intention. ${ }^{102}$ He also hints that he himself at one point had some affiliation with certain chains of transmission of a khirqa, although he does not specify which one(s). ${ }^{103}$

$99 \quad$ Ibid. pp. $172-185$.

100 As is clear from the eulogy Ibn Taymiyya wrote for Ibn Abī 'Umar, cf. Ibn Rajab, Dhayl, vol. 4, p. 181 .

101 There are over thirty references to al-Jīlānī in the printed edition of Ibn Taymiyya's $M F$. He often extols him when he mentions him in relation to correct Sufism, and acknowledges him as a knower of God ('ârif). He also quotes him several times as a spokesperson of the Hanbalī position in theological discussions; See for instance: MF: vol. 3, p. 222, and p. 264, vol. 27, p. 12; see also his al-Jawāb al-bāhir fì zuwwār al-maqābir (Riyad: al-Maktaba al'arabiyya al-sa'ūdiyya, 1984) p. 66. He quotes portions of al-Jīlānī's creed in al-Fatwā alhamawiyya al-kubrā (Beirut: Dār al-kutub al-ilmiyya, 1985) pp. 50-51. Ibn Taymiyya also has a commentary on several sections from al-Jīlāni’s Futūh al-ghayb ( $M F$, vol. 10, pp. 455552). However, it has been noted that this commentary seems to be a revision rather than a complementary text, so that it does not add much to the possibility of his affiliation with al-Jīlānī, cf. Michel "Ibn Taymiyya's Sharh,” p. 6.

Ibn Taymiyya, $M F$, vol. 11, p. 511; and also his Minhāj al-sunna al-nabawiyya fì naqd kalām al-shĩa al-qadariyya, ed. Muḥammad Rashād Sālim (Riyad: Jāmi'at al-imām Muhammad b. Sacūd al-islāmiyya, 6891), vol. 8, pp. 43-47. This attitude was already noted by Schallenbergh, "Intoxication and Ecstasy," pp. 459-46o.

103 See: Ibn Taymiyya, Minhāj al-sunna, vol. 8, p. 47: "wa-qad katabtu asānīd al-khirqa, liannahu kāna lanā fìhā asānìd, fa-bayyantuhā li-yu'raf al-ḥaqq min al-bāțil." 
Thus, like Muwaffaq al-Dīn, Ibn Taymiyya's exact relationship with al-Jīlānī's line of Sufism remains a puzzle.

We do find several hints that some form of Qādirī Sufism was present in his direct surroundings. In his Wașiyya, Ibn Taymiyya forbids the misuse of any epithet that indicates one's affiliation with a particular group, and names 'alQādirī' among several others as an example. ${ }^{104}$ Elsewhere, in a fatwa, we find that he was once asked whether it is permissible to say that al-jīanni is the best of (Sufi) shaykhs and Ibn Hanbal the best of imams, to which he replies that this is forbidden when such claims are made without proof and give rise to division among the people. ${ }^{105} \mathrm{~A}$ very similar issue is addressed in Ibn Taymiyya's Bughyat al-murtād, in a passage where he attacks the exaggeration that exists among some people in their praise of Ibn Hanbal and al-Jīlānī. ${ }^{106}$ Now, it will not have been by chance that Ibn Hanbal and al-Jīannī are mentioned together in two separate works. We may take this as an indication that some kind of Hanbalī-Qādirī affiliation did exist in Damascus around the beginning of the eighth/fourteenth century, and that its visibility was thus that Ibn Taymiyya felt compelled to express his own views about it on paper. Moreover, this also casts a shadow of doubt over the above-mentioned claim attributed to Ibn Taymiyya in one of the manuscripts used by Makdisi regarding the superiority of the Qādirī path.

An important concluding observation to be made, then, is that while Makdisi's article that links Ibn Taymiyya to al-jīlānī is still talked about to this day, it is not likely that al-Wāsițī would have found some sort of Qādirī Sufi shaykh in his Hanbali master. What he did find was a shaykh who walked in the footsteps of the Hanbali zuhhād of Damascus. As we shall see, it was, above all, the mixture of traditionalist theology and charismatic leadership, the same ingredients that had made the Maqdisiss of the Șalihịiyya so successful, that attracted him to Ibn Taymiyya.

\subsection{In the Company of Ibn Taymiyya: Șụba under the Shaykh al-Islām}

Speaking of himself in the third person, al-Wāsiți sums up his life's journey leading up to Damascus as follows in his Mukhtașar sïrat Rasūl Allāh:

Someone in whom God (ST) aroused the resolution to taste something of the spiritual stations (maqāmāt) to which the [Sufi] folk (al-qawm) allude maintained a state of renunciation $(z u h d)$ for period of time in order

104 Ibn Taymiyya, $M F$, vol. 3, p. 416.

105 Ibid. vol. 20, p. 291.

106 Ibn Taymiyya, Bughya, p. 493. 
to seek a path through which he may reach something of these lofty states $(a h w \bar{a} l)$ and sublime tastes $(a d h w \bar{a} q)$ - such as love for God (T), longing for Him, fearing Him, being patient with His commands and decrees, trusting in Him, being content with Him, and other such things; and also their elevated branches - such as divine manifestation (tajalli $)$ and concealment (istitār), annihilation ( fana $\left.\bar{a}^{3}\right)$ and subsistence (baqa $\left.\vec{a}^{\prime}\right)$, intoxication (sukr) and sobriety (sahw $)$, and other such things. His travels in search of that became long and his hope and expectation became strained after almost fifteen years of ill luck, not finding any gleam of light; being eager, but not seeing a beginning nor a ray of sunlight; persevering in whatever the seekers [of God] persevere by different kinds of spiritual struggles (mujāhadāt) and different ways to remember God and draw near unto Him (al-adhkār wa-al-taqarrubāt). Until he came to a point that he felt disgusted by his desperate resolution to deviate on the path of those who are shaykhs by outward appearance only among the people. But God (ST) was kind to him, for He made him meet a murshid who was a refuge of succor for him. ${ }^{107}$

This murshid - a guide on the spiritual path in Sufi terminology - was none other than the Hanbalī shaykh al-Islām Taqī al-Dīn Aḥmad Ibn Taymiyya. By then well into his thirties, he was some four years younger than al-Wāsiți. Yet, our Iraqi Sufi soon recognized him as the shaykh he had been seeking ever since he departed from his homeland. How exactly al-Wāsițī ended up finding him when he came to Damascus is never disclosed, but one can imagine he would not have been difficult to miss. Ibn Taymiyya had by then already made a name for himself as a talented Hanbali jurist and theologian. Below we will go through the final pages of al-Wāsițīs autobiography to see what his first impressions of Ibn Taymiyya and his circle can tell us about them.

Before we start, it must be noted that the information we are provided with here must, strictly speaking, specifically be situated within the time frame of the ending of the seventh/thirteenth century until 705/1306, when Ibn Taymiyya went to Egypt. ${ }^{108}$ Several studies have shown that over time the Taymiyyan circle became somewhat divided, in part due to the many tribulations the group's leader had to endure, but perhaps also due to conflicting opinions

107 Al-Wāsițī, Mukhtașar sīrat rasūl Allāh, f.2b.

108 Al-Wāsiṭi stayed in Damascus and would never again see his shaykh. Also worth mentioning is the fact that al-Wāsițī would have been a witness to the Mongol attacks on Damascus around this period of time, though he makes no mention of this anywhere. 
regarding his rational approach to theology and some of his legal opinions. ${ }^{109}$ While this is an important development for the study of their dynamics, the remainder of the current chapter will focus on a period of time when these issues did not yet give rise to the kind of fragmentation that appears to have afflicted the group later on - especially after al-Wāsițî's passing.

Since our Iraqi Sufi wrote his autobiography at the beginning of the eighth/ fourteenth century, we can be certain that he entered a master-disciple relationship (suhba) with Ibn Taymiyya rather soon after his arrival in the capital of Shām. ${ }^{110}$ The Hanbalī shaykh al-Islām was at that time head of the Dār alHadīth al-Sukkariyya and teacher at al-Madrasa al-Hanbaliyya al-Sharīfiyya. On Fridays he also gave Qur'anic exegesis from the Hanbalī chair in the Umayyad Mosque. ${ }^{111}$ His activities were thus largely concentrated within the walls of the old city. Al-Wāsiți in all likelihood took up residence in al-Hanbaliyya alSharīfiyya, which may very well have been catered for by Ibn Taymiyya. ${ }^{112}$

We can get a glimpse of what al-Wāsițīs daily life under his shaykh's guidance may have looked like thanks to the account of Sirāj al-Dīn 'Umar b. 'Alī al-Bazzār (d. 749/1349), who had likewise been a student of the Damascene scholar. ${ }^{113}$ He relates that after sunrise Ibn Taymiyya would sometimes leave his mosque - likely the Sukkariyya madrasa where he lived - with his companions (ma'a man yașhabuhu) to attend an audition of prophetic traditions (samā' al-hadith). Upon return the shaykh al-Islām would issue fatwas and see to the needs of people until the break of midday prayer (al-zuhr), and then

109 On this, see in particular: Bori, "The collection and edition of Ibn Taymiyah's works," pp. 56-59; and also by Bori: Ibn Taymiyya wa-Jamāeatuhu," p. 43.

110 Al-Wāsițī, Rị̣la, p. 49, where al-Wāsiți explicitly says that his age is the beginning of the eighth century of the Prophetic Hijra (fì 'așrī hädhā fì ra's al-sab'imia min al-hijra alnabawiyya).

111 When his father passed away in 683/1284 Ibn Taymiyya took over directorship of the Sukkariyya. He retained this position for the remainder of his life, even during his absence from Damascus, cf. al-Dimashqī, al-Dāris, vol. 1, pp. 57-59. About a year later Ibn Taymiyya also took over his father's chair at the Umayyad Mosque, cf. Ibn Rajab, Dhayl, vol. 4, p. 495. In 695/1296 Ibn Taymiyya's shaykh Zayn al-Dīn al-Munajjā passes away and he takes over his position as head teacher at al-Hanbaliyya al-sharifiyya, which he retained until 716/1317, when he was replaced, cf. al-Dimashqì, al-Dāris, vol. 2, pp. 57-58.

112 Neither the relevant chronicles nor al-Wāsiți’s own works explicitly mention where the latter lived in Damascus. However in a manuscript on $s a m \bar{a}^{c}$ al-Wāsițī writes in the colophon that he finished it in the early morning of a Friday, in al-Madrasa al-Hanbaliyya, which suggests that he lived there; cf. al-Bulgha wa-al-iqnā' fi hall shubhat mas'alat al$s a m \bar{a}$, The National Library of Israel, JER NLI AP Ar. 158/7: f. 72b.

113 Al-Bazzār claims he was a witness to Ibn Taymiyya's daily routine, as he would stay by his shaykh's side for the entirety of the day and the majority of the night, cf. Sirāj al-Dīn 'Umar b. 'Alī al-Bazzār, al-A'lām al-'aliyya fì manāqib shaykh al-islām Ibn Taymiyya, ed. Ṣalāḥ al-Dīn al-Munajjid (Beirut: Dār al-kutub al-jadīd, 6791), p. 38. 
continue like that until the sunset prayer (al-maghrib). The final hours of the day were reserved for his companions. He would have a class during which someone would read passages from his writings out loud, and he would give commentary and inform them of the curiosities and subtleties of the subject under consideration. Thus they would go on until the evening prayer $(a l-i s h \bar{a})$, after which they proceeded in like manner, treating the religious sciences ( $a l-$ 'ulüm) late into the night. ${ }^{114}$

As al-Wāsiṭī accompanied Ibn Taymiyya, his entire perspective on religion was soon engrossed in the way of the Hanābila. This compelled him to devote himself to the study of a variety of texts from the traditionalist curriculum, and before long he made his definite conversion to the Hanbali madhhab. In jurisprudence he read Muwaffaq al-Dīn's al-Käfi under Majd al-Dīn Ismāîl b. Muhammad al-Harrānī (d. 729/1329), possibly in the Jawziyya madrasa. ${ }^{115}$ As befits a traditionalist, he also occupied himself with hadith, although it is unclear how far he delved into the subject. ${ }^{116}$ Under Ibn Taymiyya's guidance he was directed to focus on the Prophet's biography (al-Sìra) of Ibn Hishām (d. 218/833) and its revision by Ibn Isḥāq (d. 150/767). Al-Wāsițī would later compose a summary of this well-known book, from which I have quoted at the

114 Ibid. p. 39.

115 For al-Wāsițī's study of al-Kāfí, see: Ibn Rajab, Dhayl, vol. 4, p. 382. Majd al-Dīn al-Ḥarrānī was considered a specialist in this particular work and one of the chief shaykhs of the Ḥanbalīs in Damascus, see: Ibn Kathīr, al-Bidāya, vol. 14, p. 168, and Ibn Rajab, Dhayl, vol. 4, pp. 532-535, where we also find that he passed away in the Jawziyya madrasa, on which I base my assumption that he would have taught there.

116 Cf. Ibn Rajab, Dhayl, vol. 4, p. 381. As would be expected of a traditionalist, al-Wāsițī refers to the six canonical collections of hadith and Ibn Hanbal's Musnad several times in his writings. These would certainly have been studied in the Taymiyyan circle; see al-Wāsițīs Miftāh al-márifa wa-al-ibāda, p. 258; Qāंida fı ítibār ahl al-khayr wa-ghayrihim, p. 135; 'Umdat al-tullāb, p. 195. In the latter treatise he also mentions the following other works in this genre: the Muwațtá of Mālik (d. 179/795), the Șaḥị̣ works of Abū Bakr al-Ismāî̀lī (d. 371/981), Abū Bakr al-Burqānī (d. 425/1033), Abū Ḥātim Ibn Ḥibbān al-Bustī (d. 354/965), al-Hākim al-Nīsābūrī (d. 405/1014), Abū Bakr al-Jawzaqī (d. 388/998), Abū Nu'aym alIṣbahānī, and al-Baghawī (d. 516/1122). Also, the Musnad works Isḥāq Ibn Rāhwayh (d. 238/852), Ibn Abī Shayba (d. 235/849), 'Abd b. Ḥamīd al-Kashshī (d. 249/863), Muhammad b. Hārūn al-Rūyānī (d. 307/919), 'Abd Allāh b. 'Abd al-Raḥmān al-Dārimī (d. 255/869), Abū Ya'lā al-Mawșilī (d.307/919), Abū Dāwud al-Ṭayālisī (d. 204/818), Mūsā Abū Qurra al-Zabīīi (d. unknown). Also, abridgments of such compilations, such as Jam' bayna alȘahịhayn by al-Ḥumaydī (d. 488/1095), Jāmi` al-ușūl by Ibn al-Athīr (d. 6o6/1210), and al-Mașābīh by al-Baghawī. And, finally, the Aḥkām works of hadīth by 'Abd al-Haqq alIshbilī (d. 581/1185), 'Abd al-Ghanī al-Maqdisī (d. 6oo/1203), Majd al-Dīn Ibn Taymiyya (d. 653/1255), and Ḍiyā' al-Dīn al-Maqdisī (d. 643/1245). 
beginning of the current section. ${ }^{117}$ That he took his shaykh's advice to heart is apparent from the many titles he was familiar with from the Sira-genre. ${ }^{118}$ And as we shall see in the next chapter, this would later inspire him to allot a crucial role to the Prophet in his own teachings on Sufism.

Another subject he studied in Damascus that deserves special attention due to its tremendous influence on his formulation of Sufism is theology. Al-Wāsițî̀s writings contain references to several theological works that he was presumably introduced to among the Hanbalīs. The Kitāb al-tawhìd of Muhammad b. Ishāq Ibn Khuzayma (d. 446/1054) and the Kitāb al-naqd of 'Uthmān b. Sa'ìd al-Dārimì (d. 28o/894) are recommended by him on two separate occasions as reliable books on the doctrines (madhähib) of the Salaf. ${ }^{119}$ Biographical sources show that both books were indeed popular among traditionalists of the period that concerns us. It is known that the Kitāb al-tawhid was in fact transmitted by Jamāl al-Dīn Yūsuf al-Mizzī (d. 742/1341), a renowned Shāfíi traditionalist from Ibn Taymiyya's Damascene circle. ${ }^{120}$ Ibn Taymiyya was also

117 Ibn Rajab, Dhayl, vol. 4, p. 381. In the introduction to this Sïra's summary al-Wāsitī implies indirectly and without mentioning his name that it was indeed Ibn Taymiyya who had directed him to the study of it, cf. al-Wāsițī, Mukhtașar sìrat rasūl Allāh, f.2b-3a.

118 Al-Wāsițī mentions the Maghāzī of Mūsā b. 'Uqba (d. 141/758) and the Sirra works of al-Wāqidī (d.207/823), Yahya b. Sa'īd al-Umawī (d. 194/809), and Muhammad Ibn 'Ā'id (d. 232/847). On Daläil al-nubuwwa, a subgenre of Sīra, he was familiar with the works of Abū Nu'aym al-Iṣbahānī, Abū Bakr al-Bayhaqī (d. 458/1066), Abū al-Ḥasan 'Alī al-Māwardī (d. 434/1043), 'Abd al-Jabbār al-Hamadhānī (d. 415/1024), and the Ithbāt nubuwwa Muhammad by Abū al-'Abbās Aḥmad al-Qurțubī (d. 656/1258). On the virtues of the Prophet he names: Ikhtișār sharaf al-Muștafā by Qādī 'Iyāḍ (d. 544/1149) and al-Wafā’ bi aḥwāl al-Muștafā by Abū al-Faraj b. al-Jawzī. In addition, on the prophets in general he mentions Qișaș al-anbiyä’ by al-Kisā'ì (d. unknown) and on the Prophet's Companions al-Ṭabaqāt al-kubrā of Ibn Sa'd (d. 168/784) and the Isti'āb fì ma'rifat al-așhāb of Ibn 'Abd al-Barr (d. 463/1071). For this list, see al-Wāsițì's 'Umdat al-țullāb, p. 195, and his Miftāh al-márifa wa-al-ibāda, p. $25^{8}$.

119 For al-Wāsițî's mention of both works, see: Wașiyya ilā ba'd quḍāt al-Shām, p. 141, and Qã ida fì al-umūr allatì yanbaghī an takūn hamm al-sālik, p. 192. Also, both in al-Wāsițīs Risāla fi ithbāt, p. 40 and in the Wașiyya ilā ba'd quḍāt al-Shām, p. 143 he cites from 'Uthmān b. Saīid al-Dārimī, Naqụ al-imām Abī Sa'ìd 'Uthmān b. Sa'ìd 'alā al-Marīsīal-Jahmī al-'anìd fìmà 'ftarā 'alā Allāh ('azza wa-jalla) min al-tawhìd, ed. Abū 'Āṣim al-Shawāmī al-Atharī (Cairo: al-Maktaba al-islāmiyya li-al-nashr wa-al-tawzī', 2012), p. 67.

An important source is Aḥmad Ibn Ḥajar al-Asqalānī: in his al-Mujam al-mufahras awtajrìd asānīd al-kutub al-mashhūra wa-al-ajzāò al-manthūra, ed. Muhammad Shakkūr Maḥmūd al-Ḥājī Amrīr al-Mayādīnī (Beirut: Mu’assasat al-risālah, 1998), p. 55 we find that the Kitāb al-naq d़ was transmitted to him via the Iraqi Ḥanbalī, Muhammad b. 'Abd alMuḥsin al-Dawālībī (d. 728/1328) (on him, see: al-Ṣafadī, al-Wafì, vol. 4, p. 23). On p. 52 of the same work Ibn Hajar relates that the Kitāa al-tawhìd was transmitted to him via alMizzī. Furthermore, we find proof that the latter work was already popular in Hanbalī 
thoroughly familiar with both the Kitäb al-tawhìd and the Kitāb al-naqd.. ${ }^{121}$ Another treatise of theology that must have been at al-Wāsițī's disposal in Damascus is the creed of the Hanbali hadìth-scholar 'Abd al-Ghanī al-Maqdisī, the aforementioned cousin of Muwaffaq al-Dīn. ${ }^{122}$ Finally, there is al-'Aqìda alWäsitiiyya, a creedal text composed by Ibn Taymiyya in 698/1298-1299, which he will evidently have heard directly from the Hanbalī shaykh himself. ${ }^{123} \mathrm{Al}-$ Wāsițī mentions this creed in his Umdat al-țullāb, where he comments that it is sufficient for someone who seeks guidance (al-mustarshid), as it provides the essential knowledge of religion that is required to hopefully reach the final station of arrival unto God and spiritual stability (maqām ${ }^{a n}$ min al-wușūl wa-altamkin). ${ }^{124}$

For al-Wāsiți there was thus an indissoluble bond between theology and spirituality, and it is herein that we find one of the main reasons why he ultimately came to value Ibn Taymiyya so greatly. His 'Umdat al-țullāb once more provides us with a notable illustration in that regard, in a passage where he discusses how under the influence of philosophy and kaläm the Muslim world of his time has become dominated by erroneous views in the field of doctrine:

But God has bestowed His blessing upon the Muslims in this age through the appearance of our shaykh and imam, the master of Islām, the lamp in the darkness (miṣbāḥ al-zalām), Taqī al-Dīn Abū al-Abbās Aḥmad Ibn Taymiyya - may God make the people profit by preserving him! - for he clarifies to the Muslim community (umma) their original path (minhajjahā $a l-a w w a l)$ with regard to their religion and articles of faith ('aqāid). ${ }^{125}$

Without mentioning Ibn Taymiyya by name, but certainly intended as an indirect reference to him, al-Wāsițī makes a complimentary statement in his Mìzān al-shuyūkh:

circles well before our period under consideration, as it was studied among them in fifth/ eleventh century Iraq, cf. Ibn Rajab, Dhayl, vol. 1, p. 66.

121 Ibn Taymiyya has extensive and often lengthy quotations from both doctrinal works in his Bayān talbiss al-Jahmiyya, see for instance: vol. 2, pp. 64-65 for al-Dārimī, and vol. 4, p. 490 for Ibn Khuzayma.

See: al-Wāsițī's Risāla fì ithbāt, p. 34, where he cites 'Abd al-Ghanī concerning a hadīth, as found in the latter's al-Iqtișād fí al-i'tiqād, ed. Aḥmad b. 'Ațiyya b. 'Alī al-Ghāmidī (Medina: Maktabat al-'ulūm wa-al-hiikam, 1993), p. 42.

123 For the date of composition, see Ibn Taymiyya's $M F$, vol. 3, pp. 163, 194 \& 203.

124 Al-Wāsițī, 'Umdat al-țullāb, p. 203

125 Ibid. 
Every century God saves the Muslim community by electing distinguished men to be assistants (anșār) of His religion. They warn the people about the newly invented things and innovations that have come into being. They succeed one another, rectifying what the people have corrupted of the [Prophet's] Sunnas. ${ }^{126}$

It was, above all, the Damascene shaykh's fearless and outspoken stance as an activist of the traditionalist creed that convinced al-Wāsiți of his high rank as one of the revivers of the Sunna. ${ }^{127}$ In his view, God had appointed Ibn Taymiyya for this cause by having blessed him with the intellectual capabilities that enabled him to effectively combat the innovations that had crept into the original doctrine of the Prophet and the righteous predecessors (al-Salaf al-șalih).

But it wasn't Ibn Taymiyya's theological competence alone that will have earned him al-Wāsițīs loyalty. He was seen by his disciples as someone who emanated a pious charisma in his bearing and daily routines. His student alDhahabì describes him as a man of medium height who inspired reverence ('alayhi mahāba), with fair skin, striking eyes, short black hair, and a round beard. ${ }^{128}$ Both he and several other biographers concur that he dressed moderately, wearing cheap sandals, a jurist's cloak, and a turban, and that he was content living in poverty, having but few possessions and receiving only a small stipend for his work. ${ }^{129}$ According to al-Bazzār, the Ḥanbalī shaykh would spend his nights in solitude, reading from the Qur'an until it was time for morning prayer (al-fajr). Before joining the congregation to lead the prayer he would first perform two cycles of voluntary prayer by himself, which he followed up with invoking God forty times with His divine names al-Hayy (the Living) and al-Qayyūm (the Sustainer). ${ }^{130}$ After concluding the communal

126 Al-Wāsițī, Mīzān al-shuyūkh, pp. 229-23o. A very similar statement is made by al-Wāsițī in al-Tadhkira, p. 40.

127 Note that al-Wāsițī's description of Ibn Taymiyya bears close resemblance to the concept of the 'reviver of the religion' (mujaddid al-dìn). According to a prophetic tradition, every century will know such a mujaddid, sent by God to revive and purify His religion. On this, see for instance: Emeri van Donzel, "Mudjaddid." In EI2: vol. 7, p. 29 o.

128 I refer to the summarized biography of Ibn Taymiyya, composed by al-Dhahabī, which is edited and translated by Caterina Bori in "A New Source for the Biography of Ibn Taymiyya." BSOAS, vol. 67, no. 3 (2004): p. 334 for the Arabic, and pp. 343-344 for the translation.

129 For al-Dhahabī, see: Bori, "A New Source," p. 346. For others, see: al-Bazzār, al-A'tām, pp. 47-48, and 51; Ibn Rajab, Dhayl, vol. 4, p. 5 o9.

130 Ibn Taymiyya's invocations between the voluntary and the obligatory morning prayer are not mentioned by al-Bazzār, but can be found in: Shams al-Dīn Muhammad Ibn Qayyim al-Jawziyya, Madārij al-sālikìn bayna manāzil iyyāka naçbudu wa-ikkāka nastaīn, ed. Muhạammad al-mu'tașim bi-Allāh al-Baghdādī (Beirut: Dār al-kitāb al-'arabī, 1996), vol. 1, p. 446, and again in vol. 3, p. 248. 
prayer he again recited specific invocations and supplicated to God in accordance with the Sunna, and then continued with the remembrance of God (dhikr) until the sun rose, not speaking with anyone except out of absolute necessity. ${ }^{131}$ This routine reflects the kind of piety characteristic of the Hanbali zuhhād of the Banū Qudāma. The same goes for the hagiographic tales that we find attributed to Ibn Taymiyya by his followers, indicating that he was no ordinary man in their eyes. They for instance relate that his supplications to God would be answered and that he was granted miracles (karāmāt), such as the gift to foresee what would come to pass. ${ }^{132}$ We can assume that it were these kind of qualities that made Ibn Taymiyya popular and earned him the recognition of his admirers as a complete master in whom traditionalist learning and piety came together. To al-Wāsițī, and to his companions in general, he was indeed that.

As Ibn Taymiyya rose to fame, there formed an intimate circle (jama $\left.\bar{a}^{c} a\right)$ of predominantly Hanbalīs and Shāfi'is who followed him, most likely on the basis of his erudition, charisma, and competence as a leader. Caterina Bori has observed that while he will surely have had numerous students studying under him in the madrasas where he taught, this inner circle appears to have been a rather small group of men who shared a strong sense of loyalty and elitism among themselves. ${ }^{133}$

Bori argues furthermore that their support of Ibn Taymiyya should be read beyond the framework of madhhab, though I would add that this only goes for jurisprudence. ${ }^{134}$ When it comes to theology, it is exactly in the madhhab that we find the common ground between all members of his jama $\bar{a}^{c} a$. Both the Hanbalīs and the Shāfi īs who followed Ibn Taymiyya probably did so because they believed in his ability to support the cause of the traditionalist school, the Ahl al-Hadīth. In his autobiography, al-Wāsiți explicitly notes their shared affiliation with traditionalism as a characteristic element of the group:

Their principles of faith $(u s \bar{u} l)$ are not those of the speculative theologians (mutakallimin). Rather, the principles of their beliefs are based on Qur'anic verses and authentic reports (al-akhbār al-șahịha). They take the divine attributes (șifāt) as they are mentioned, without metaphorically interpreting them $\left(t a^{\prime} w \bar{l} l\right)$, stripping them of their meanings $\left(t a^{t} t \bar{l} l\right)$, or assimilating them to those of creatures (tashbih). They affirm that

\footnotetext{
131 Al-Bazzār, al-Aֹ⿳亠̄m, pp. 37-38.

132 Ibn 'Abd al-Hādī, al-'Uqūd, pp. 191-193; Ibn Qayyim al-Jawziyya, Madārij al-sālikīn, vol. 2, p. 458; al-Bazzār, al-A'ām, pp. 56-62.

133 Caterina Bori, "Ibn Taymiyya wa-Jamā'atuhu," pp. 30-33.

134 Ibid. p. 43.
} 
their concrete realities (haqūiqahā) relate to God in a way that befits Him, such as His sitting [on the Throne] (istiw $\bar{a}$ ) or descent [from the heavens] (nuzül), and all other attributes.... They know that their Lord is above them (min fawqihim) and thus worship Him as it has come down in the holy texts (nușuṣs), since these demonstrate that He is above the Throne with His divine essence and attributes with an aboveness (fawqiyya) that befits His majesty and magnificence. ${ }^{135}$

And not only did they adhere to the same theological school, but as is evident from a letter al-Wāsiți sent to several members of Ibn Taymiyya's jamãa $a$, they were also willing to join their leader in his activism for its sake. After summing up all the deviating groups of his age he had come across, our Iraqi Sufi tells them: "I have traveled the world, but I have not come across anyone who stands up against their ilk save you."136 Evidently, he valued their joint effort to strive for the traditionalist cause by censuring all those who deviated from their notions of normativity as one of the group's key features.

There is little doubt that their activism emerged from the genuine conviction that the traditionalists were the last group that truly represented the original doctrine of the Ahl al-Sunna wa-al-Jamã a, and were, as such, 'the saved sect' (al-firqa al-näjiya), or 'the victorious group' (al-țāiffa al-manșūra). This concept of the saved sect is based on several hadiths wherein the Prophet is supposed to have predicted the splitting up of the Muslim community into a number of sects, only one of which will still follow the pure, unadaltered religion of God. ${ }^{137}$ That Ibn Taymiyya was not shy to lay claim to this status for his own theological school is evident from his aforementioned creed, al-Wäsitịyya. In its introduction he calls it "the creed of the saved, victorious sect (itiqa a d alfirqa al-näjiya al-manșūra)," that being "the Ahl al-Sunna wa-al-Jama'a," by

135 Al-Wāsițī, Riḥla, pp. 45-46.

136 Al-Wāsițī, al-Tadhkira, p. 38.

137 A well-known hadith in that regard tells that the Muslims will split up into seventy-three sects, only one of which will be on the truth, that being 'the community' (al-jamāa $a$ ), see for instance: Aḥmad b. Muḥammad Ibn Ḥanbal, Musnad al-imām Aḥmad b. Hanbal, ed. Shu'ayb al-Arna'ūț, 'Ādil Murshid, et al. (Beirut: Mu’assasat al-risāla, 2001), vol. 28, p. 135. According to another hadìth the Prophet said: "There will continue to be a group (țā'ifa) in my community (ummatī) who are manifestly upon the truth. They will not be harmed by those who forsake and oppose them until the coming of the [final] hour," see for instance: Abū al-Ḥasan b. al-Hajjāj Muslim, al-Musnad al-șaḥịh al-mukhtașar bi-naql al'adl 'an al-'adl ilà Rasūl Allāh (șallā Allāh 'alayhi wa-sallam), ed. Muhammad Fu'ād 'Abd al-Bāqī (Beirut: Dār iḥyāà al-kutub al-'arabiyya, 1955), vol. 3, p. 1523. 
which we know he actually means the Ahl al-Hadīth. ${ }^{138} \mathrm{Al}$-Wāsițī takes it a step further than his Damascene master and seems to have been convinced that their jamāa $a$ itself was the saved sect. In the same letter from which we have quoted above he tells his Taymiyyan companions: "If God wills it, I hope that you will be the victorious group (al-țăifa al-manșüra), who will not be harmed by those who forsake and oppose them, and who will be in Greater Syria (alshām)."139

Al-Wāsițīs depiction of the jamā'a also tells us that it included a number of other authoritative and charismatic figures besides Ibn Taymiyya. Indeed, as will become apparent in the last section of this chapter, the Taymiyyan circle was not a mere gang of slavish disciples, but comprised individuals who were themselves climbing the ladder of the scholarly scene of Damascus. It is perhaps for that reason that his autobiography neither mentions Ibn Taymiyya by name nor alludes to his person indirectly. Instead al-Wāsiți only speaks of the ța $i$ ifa he found in Damascus and then continues to refer to them as "our shaykhs" (mashāyikhunā). The following passage in particular indicates that he must have been immensely impressed not only by the circle's leader, but by all its members:

I found that they are men who possess intimate knowledge of the days of Prophethood ('ärifin bi-ayyām al-nubuwwa), the biographies of the Companions, the meanings of the revelation, and the principles of beliefs (ușūl al-'aqā'id) as derived from the Book and the Sunna. They possess intimate knowledge of the tastes of the spiritual travelers [unto God] ('ârifin bi-adhwāq al-sālikīn), their beginnings, and the particulars of their spiritual states $(a h w \bar{a} l)$ which they regard as part of religious perfection (kamāl al-dīn), since the religion is incomplete without them. Their breaths (anfās) are incomparable to those of their contemporaries, whether jurist or Sufi. Their breaths can only be compared to those of the first three centuries [after Hijra] in the time of the Companions, the Followers (täbi ìn), and those who followed after them. By being together with them and seeing them it was as if I was meeting with Abu Bakr, 'Umar, 'Uthmān, and 'Alī, and with Followers such as Sa'īd b. al-Musayyab, al-Ḥasan al-Bașrī, al-Rabī' b. al-Khuthaym, Thābit al-Bunānī, and others like them. By seeing them, it was as if I was meeting with Mālik, al-Shāfi 'ì, the two Sufyāns [Ibn 'Uyayna and al-Thawrī], the two Ḥammāds

138 Ibn Taymiyya, al-'Aqïda al-wāsitiiyya, in $M F$, vol. 3, p. 129, and he makes another reference to it on p. 159 .

139 Al-Wāsițī, al-Tadhkira, p. 41. 
[Ibn Zayd and Ibn Salama], Ibn al-Mubārak, Ishāa [Ibn Rāhwayh], Aḥmad Ibn Hanbal, and their peers and equals. ${ }^{140}$

In al-Wāsitị̂s comparison of his Damascene shaykhs to Muslim authorities from the first centuries of Islam we may recognize a way of showing deep reverence that is typical of the classical traditionalist scene. ${ }^{141}$ By connecting them to the time of the Salaf, which they themselves regarded as the most sound and glorious period for Islam, he meant to distinguish them from the majority of his contemporaries who were at odds with the traditionalist school. This may explain the sense of elitism among them of which Bori has made note, which may very well have been the trend among Damascene traditionalists in general as proponents of what was by then a minority position in theology.

No less striking in the above quote is al-Wāsiți’s use of Sufi terminology in relation to his newly found companions. He calls them "men who possess intimate knowledge" ('arifín), and specifically of the "tastes of the spiritual travelers" (adhwāq al-sālikin), by which he seems to imply that they have been exposed to something of the spiritual experiences of the Sufis. He also states that their "breaths" (anfās) are unique in their age, which seems to imply that their sincere devotion to God is peerless. In Sufi terminology, 'breath' is sometimes used in relation to the notion that the Sufi is constantly aware of God. It is related from al-Junayd, for instance, that the servant's every breath should be devoted to God, and a Sufi poet reportedly said: "To God belong those breaths that are breathed for Him.."142 The use of these terms indicates that, unlike the Shāfi'i fuqahā' al-Wāsiṭi had accompanied earlier in his journey, these Damascene shaykhs were not merely dry jurists whose profession was nothing more than an intellectual exercise. Their knowledge actually served a deeper purpose.

140 Ibid. p. 45 .

141 We find several examples in Hanbalī sources where scholars of repute are being compared to the early generations of the Salaf. See for instance: al-'Ulaymī, al-Manhaj al-ahmad, vol. 4, pp. 149-150, where it is related with regard to Muwaffaq al-Dīn that "when you saw him, it was as if you saw one of the Companions." In Ibn Rajab's Dhayl, vol. 4, p. 180, it is related that al-Birzālī described Ibn Abī 'Umar as "a successor of the righteous predecessor in the majority of his states $(a h ̣ w a \bar{l})$." And another member of the Banū Qudāma, 'Imād al-Dīn Ibrāhīm (d. 614/1218), was reportedly compared to Sufyān al-Thawrī, cf. Leder "Charismatic Scripturalism," p. 302.

142 'Abd Allāh b. 'Alī al-Sarrāj, Kitāb al-luma'fi al-tașawwuf, ed. Reynold A. Nicholson (Leiden: Brill, 1914), pp. 347-348. See also for instance: al-Qushayrī, al-Risāla, for the term 'anfās,' vol. 1, p. 196, and for the term 'dhawq,' see vol. 1, pp. 177-178. 
While he certainly does not name them Sufis anywhere in his writings either, he did find that a certain spiritual disposition was inherent to their preoccupation with upholding God's religion and their embodiment of the way of the Salaf. This, he says, "is a magnificent task for the sake of their Lord through which their hearts have become enraptured out of bewilderment, awe, and

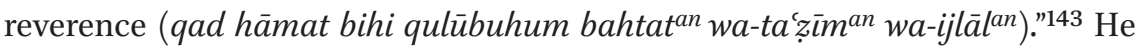
even admits that they do not reach the kind of self-effacement (iștiläm) in God that he had witnessed among the Shädhiliyya, and which he clearly greatly admired. However, he states in their defense, "it does not befit someone who is concerned with upholding the religion and disseminating its laws and rites to be self-effaced in the way of these [Shādhilīs] who only have room for their Creator." ${ }^{144}$ He explains later on in his autobiography that this is why someone who seeks the realities of Sufism (haqä̉iq al-tașawwuf) should do so among its specialists rather than among the jurists. ${ }^{145}$ It is thus obvious that he differentiated between his shaykhs from Alexandria as specialists in Sufism and his shaykhs from Damascus as qualified traditionalist scholars.

This eventually leads al-Wāsiți to a surprising conclusion that marks the end of his autobiography. In his final reflections he writes that those who love his Damascene shaykhs (muhibbì mashāyikhinā) may notice that he credits both them and his Shādhilī masters with intimate knowledge (ma'rifa). He imagines that they may subsequently wonder what special trait (khusūssiyya) the Shādhilīs have that cannot be found among his traditionalist shaykhs. He replies as follows:

My response is that this special trait [of the Shādhiliss] is a penetrating mode of being (kayfryya ha a dda): by merely seeing and hearing them they induce in the seeker (al-tālib) love for God, divine attraction towards Him (injidhāb ilayhi), desire for Him, and obliviousness to all things save Him. This is the special trait they have that is for them alone.

A second signification is that they remind [people] of God when they are seen, which causes His light to come to the viewer's heart with vigor and severity, while when our [Damascene] shaykhs are seen they remind [people] of the religion, the Sunna, and the revealed law (al-shari $a)$. As for the former group, the sharía is embodied in their inner state $(h \bar{a} l)$ so that their outward appearance is enveloped by the mode of ma'rifa. As

143 Al-Wāsiṭī, Riḥla, p. 48.

144 Ibid.

145 Ibid. p. 51. His words are "shuyūkhina al-fuqahä,", which in the context of the point he is making undoubtedly refers to his shaykhs from Damascus. 
for the latter group, ma'rifa is embodied in their inner state so that their outward appearance is enveloped by the mode of sharîa. ${ }^{146}$

Even though al-Wāsițīs elucidation here bears witness to a profound appreciation for both groups, the distinctive criterion between them remained, of course, theology. He argues that, without the theological foundations ( $q a w \bar{a} \bar{a}^{\mathrm{i}} \mathrm{d}$ ) of his Damascene shaykhs, the Sufi mode of being (al-kayfiyya al-șuffiyya) of his Shādhilī brethren continues to be incomplete and baseless (maqțúa ${ }^{u n}$ là asās lah $\bar{a}){ }^{147}$ It is in the conclusion on the final page of his autobiography that he then makes a fascinating plea to God:

I hope that, out of His kindness, God (T) will accommodate me to travel the path of these [Damascene] scholars with regard to the principles and

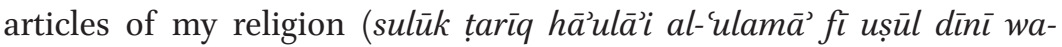
'aq $\bar{a} i d i h \bar{a}$ ) and its outward works and inward states, and that He will bring me to spiritual realization through the realities of my Sufi brothers (wa-an yuhaqqiqanī bi-ḥaqāiq ikhwānī al-șūfiyya). ${ }^{148}$

In other words, instead of disavowing the Shādhilīs on the basis of their theological affiliation, he expresses a genuine desire for divine guidance to synthesize their method of Sufism with the teachings of his Damascene shaykhs. In this final paragraph it is as if he realizes that his experience in the field of Sufism and his acquaintance with the traditionalist school placed him in a unique position. I believe that the above prayer should be read as a plea for help in the task that he now saw before him: to reformulate what he had learned of Sufism so that it could appeal to the traditionalist community of Damascus and conform to their doctrine.

This is where al-Wāsițîs autobiography ends. We must therefore rely on other sources for information regarding the remainder of his life from the beginning of the eighth/fourteenth century onwards. In doing so we find that our Iraqi Sufi would have eventually adjusted the above conclusion as his opinion of the Shädhili țăiifa changed for the worse. Although he continued to extoll Abū al-'Abbās al-Mursī as the teacher of his own shaykh, Najm al-Dīn, he became increasingly critical of Abū al-Ḥasan al-Shādhilī. ${ }^{149}$ In the latter's entry in al-Dhahabī's Tärïkh we find the following statement in that respect:

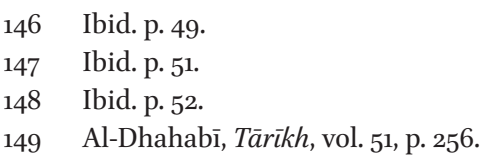


He [al-Shādhilī] has poetry and prose that contain some doubtful matters and expressions ( $i b \bar{a} r \bar{r} t$ ) that would prove difficult for him to plead in defense of. I saw that our shaykh Imād al-Dīn [al-Wāsițī] had become tepid about him towards the end [of his life] (qadfatara 'anhu fial-äkhir). He became aware of these expressions, which made him confused about the man because he had taken the Sufi path according to his method (tașawwafa 'ala țaríqatihi). ${ }^{150}$

In his biographical dictionary Ibn Rajab likewise appears to be hinting at alWāsițî's increasing distance from the Shādhiliyya, stating that he eventually abandoned all of his Sufi ways after he had decided to focus solely on the example and guidance of the Prophet. ${ }^{151}$ This development is in fact clearly expressed in one of al-Wāsițī's own works as well, which we will examine in more detail in the first section of the next chapter.

We can thus recognize two stages in the development of al-Wāsiți's conversion to Hanbalī traditionalism during his time in Damascus. His early years were distinguished by a deep-rooted conviction that Ibn Taymiyya was the shaykh of his age, appointed by God as the greatest representative of Sunni doctrine as defined by the traditionalists. In addition, we find that other scholars from the shaykh al-Islām's tă âifa also played a significant role in al-Wāsițîs vision of Islam and thus contributed to his perception of Damascus as the final destination of his journey. At this time he was profoundly influenced by the traditionalist curriculum he studied, especially in theology. This brought him to the first stage of his conversion, where he concluded that the way of the Shādhiliyya, the only manifestation of Sufism he had come to appreciate, was of no avail if it was not anchored in the theology of the Ahl al-Hadith. We may recognize the second stage as his definitive conversion to pure traditionalism, when his strong inclination towards its theology as he understood it eventually even led him to question some of the teachings he had been exposed to among the Shādhiliyya. Was he still a Sufi then?

\subsection{A Shaykh of Sufism for the Taymiyyan Circle}

As we shall now see, it is evident that al-Wāsiți eventually brought to fruition that for which he entreated God in the final paragraph of his autobiography: he formulated his own interpretation of a traditionalist Sufism that he taught to

$150 \quad$ Ibid. vol. 48, p. 274 .

151 Ibn Rajab, Dhayl, vol. 4, pp. 381-382, where he describes al-Wāsițì's abandonment of his Sufi ways in the following words: "wa-takhallā min jamīi țarāiqihi wa-aḥwälihi wa-adhwāqihi wa-sulükihi." 
spiritual seekers of God with a traditionalist background. This is confirmed in several relevant chronicles. According to al-Dhahabī, for instance, "a group of people accompanied him (jamā'at us șahabūhu)"152 and "took the spiritual way through him (tasluku bihi)." ${ }^{153}$ And Ibn Rajab concurs that "a group of our shaykhs and others have learned [Sufism] from him."154 Below we will elaborate on this role of Sufi shaykh to see what can be said regarding his position in the inner circle of Ibn Taymiyya and the way its members operated as a group.

Now, in the previous two sections we have made several observations in light of which al-Wāsițīs activity as a teacher of Sufism among Damascene traditionalists seems conspicuous. First of all, we have concluded that there is very little to be found in the relevant primary sources of the period under consideration that points to a distinct presence of Sufism among the Hanbalīs of Damascus. However, we did find that there was a tradition of a particular form of zuhd among them. Secondly, even though there appears to have been a link between al-Jīlānì and several of the city's prominent Hanbalì scholars, there remains a great deal of obscurity as to whether they actually manifested some conscious form of Qādirī Sufism. Very much in line with this is our third observation, namely, that al-Wāsiți's autobiography has unmistakably conveyed to us that he did not regard his shaykhs from the Taymiyyan circle as Sufis. All of this implies that during the time our Iraqi Sufi studied under the Hanābila of Damascus, he most likely did not receive any additional training in the Sufi way. This would mean that he himself was the architect of the Sufi doctrine he went on to actively propogate.

Based on his written works we can make a rough estimation of the years he was active as a teacher and spiritual guide. Although it is impossible to say whether he first started with penning his conceptualization of Sufism on paper or with conveying it orally, both modes of transmission were surely interconnected. The majority of his works are of a pedagogical nature, and take the reader by the hand through a step-by-step description of the different stages on the spiritual path towards God. This is especially so for the great number of precepts (sing. qāंida, pl. qawā $i d$ ) he wrote, which are mostly very brief and display a considerable degree of overlap among themselves. ${ }^{155}$ Reading

\footnotetext{
152 Ibn Rajab, Dhayl, vol. 4, p. 383 .

153 Al-Dhahabī, al-Dhayl, p. 126; see also: al-'Asqalānī, al-Durar al-kāmina, vol. 1, p. 103.

154 Ibn Rajab, Dhayl, vol. 4, p. 383.

155 I have provided a list of the published works of al-Wāsițī in the bibliography on pp. 284287. The titles in themselves display the variety of subjects pertaining to Sufism he dealt with. The pedagogical nature of the qawā id was also observed by Geoffroy, "Le traité de soufisme," p. 85. It is possible that the original manuscript of al-Wāsițīs qawā'id was written as one book, with each $q \bar{a} c i d a$ meant as a chapter (which appears to have been
} 
through his corpus of precepts often gives the impression that he may very well have taught from them during his classes, or perhaps wrote them as complimentary study material for his disciples. The relation between the role of teacher and author is, moreover, evident from a few treatises that were actually written after the request of someone, possibly a student. ${ }^{156}$ Taking this into consideration, my study of al-Wāsiți’s oeuvre has led me to believe that, in line with the dating of his autobiography, his teaching activity will have taken off in the early years of the eighth/fourteenth century. We know of at least five of his other treatises that similarly allude to their time of composition as the beginning of the century, and of one work on sama $\bar{a}^{c}$ that is dated 703/1304. ${ }^{157}$ Furthermore, I have not come across any treatise by his hand that contains even a remote allusion to an earlier date of composition. It was thus roughly during the final ten years of his life that he would have been active as teacher and author in the field of Sufism.

We may get an impression of how his role as a Sufi shaykh at that time influenced his position in the Taymiyyan jamác $a$ by looking at several references to his relationship with Ibn Taymiyya. It is obvious from the few instances in our sources where the latter is found referring to al-Wāsiți that he came to regard him as an authority in Sufism rather than simply as one of his followers. We quoted above a letter by Ibn Taymiyya from 704/1304 in which he calls him "our master (sayyidunā) shaykh 'Imād al-Dīn." 158 In the heading of a another letter, which Ibn Taymiyya sent to al-Wāsiți from Cairo between 705/1306 and 711/1311, he addresses him as follows: "To our shaykh, the imam, the knower (al-ärif), the model $(a l-q u d w a)$, the spiritual traveler $(a l-s \bar{a} l i k) . . . " 159$ Another instance is found in Ibn Taymiyya's Dar' ta'ärud al-'aql wa-al-naql, which he wrote over the course of the years $710 / 1313-717 / 1317$. In a section likely to have been com-

Geoffroy's impression, who discusses the original manuscript in "Le traité de soufisme" and treats it as a single title rather than a collective volume). However, having gone through the printed edition, It appears to me that the occasional reference of one $q \bar{a}$ cida to another rather indicates that he wrote it as teaching material as he proceeded with his

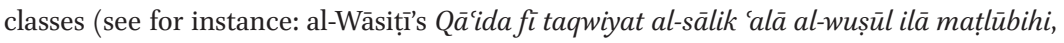
p. 119). In most cases, the qawā $i d$ are clearly separate treatises, written almost like fatwas on particular aspects of the spiritual way.

156 This is mentioned explicitly in al-Wāsițī's al-Sirr al-mașūn wa-al-ilm al-makhzūn, p. 40, Qāida fì al-umūr al-muwașșila, pp. 215-216, Q̄àida mukhtașara fì țarīq al-faqr, p. 24.

157 For the references to the early eighth/fourteenth century, cf. al-Wāsițī's Qā'ida fì așnāf alta'alluh, p. 151; Miftāh al-ma'rifa wa-al-ibāda, p. 253; al-Tadhkira wa-al-i'tibār, pp. 36, 40, \& 49; Mizzän al-shuyūkh, p. 229; and 'Umdat al-țullāb, p. 202. The treatise that is dated is alBulgha, f. $72 \mathrm{~b}$.

$15^{8}$ Ibn Taymiyya, Majmū'at al-rasā̉il, vol. 1, pp. 161 \& 170.

159 Cited by Ibn Rajab, Dhayl, vol. 4, p. 382. 705/1306 is the year Ibn Taymiyya arrived in Cairo, and 711/1311 is the year al-Wāsiți passed away. 
posed at an earlier date, he discusses a quotation from a traditionalist Mālikī Sufi by the name of Abū Muḥammad b. 'Abd al-Bașrī. He then cites our Iraqi Sufi to explain a difficult passage from this quote, referring to him as "our companion (ṣāhibūna) shaykh Abū al-'Abbās al-Wāsiṭ̂." ${ }^{60}$ A final instance comes from Ibn Rajab's Dhayl in the entry on al-Wāsițī, where we find that "shaykh Taqī al-Dīn Ibn Taymiyya would extol and praise him, and say about him that he is the al-Junayd of his time." 161 It is especially the latter comparison to alJunayd, considered by Ibn Taymiyya as a knower of God and an archetype of the authentic Sufis, which tells us that al-Wāsiți was in his eyes one of the great spiritual masters of his age. ${ }^{162}$

At the same time there is no clear-cut indication that al-Wāsiṭi was systematically instructed by Ibn Taymiyya when it came to the science of tașawwuf. This may in part have to do with the fact that the shaykh al-Islām was not himself a Sufi master in the strictest sense of the word, as previously noted. His oeuvre, more often than not, demonstrates that his primary concern in this field was of a polemical or theological nature - not because he disliked Sufism, but because he disliked certain concepts that, in his view, had unrightfully infiltrated it and (potentially) led to doctrinal errors, or even heresy. ${ }^{163}$ It is thus unlikely that there was any personal interpretation of Sufism that the Hanbali

16o For the citation of al-Wāsițī, see: $\operatorname{Dar}^{\prime} t^{\prime}{ }^{`} a \bar{r} u d$, , vol. 8, p. 507. I have not been able to identify this al-Bașrī, but Ibn Taymiyya describes him in vol. 8, p. 502. The exact date that Ibn Taymiyya commenced writing Dar' ta'ārud is not known. In vol. 1, p. 9 the editor Muhammad Rashād Sālim argues that it was most likely composed over the course of the years $713 / 1313$ up to $717 / 1317$. He bases this on a passage where Ibn Taymiyya reflects on the time when, as he says, he was in Egypt, which shows that he would have started with the book only after he returned to Damascus in 712/1313. However, as Sālim also notes in vol. 1, p. 8, there is the possibility that work on Dar'ta'ärud started in 710/1310 already. This was likely the case, since Ibn Taymiyya refers to al-Wāsiți without the usual invocation for a deceased person, which would mean that a beginning with Dar'ta'ärud was made when the shaykh was in Egypt, when our Iraqi Sufi was still alive.

$161 \quad$ Ibn Rajab, Dhayl, vol. 4, p. 382.

162 On Ibn Taymiyya's respect for al-Junayd, see for instance his Kitāb al-Ṣafadiyya, ed. Muhammad Rashād Sālim, 2 vols. (Cairo: Maktabat ibn Taymiyya, 1986), vol. 1, p. 266.

163 As mentioned earlier, we will closely examine al-Wāsiți’s Sufism in the following two chapters. Examples of Ibn Taymiyya's approach to Sufism are found, for instance, in his Kitāb al-istiqāma and in his treatises on tașawwuf and sulük published in volumes ten and eleven of MF. The majority of the treatises found in these volumes are critical, academiclike evaluations of matters pertaining to Sufism. There are only a few exceptions, such as his Amrā d al-qulüb wa-shifäuhä, in $M F$, vol. 10, pp. 138-148, which seems more practical than academic. On this issue, Elliott A. Bazzano gives a good overview of the academic discussions surrounding Ibn Taymiyya's relationship with Sufism and his polemics, cf. "Ibn Taymiyya, Radical Polymath. Part 2: Intellectual Contributions," Religion Compass 9.4 (2015): pp. 117-120. 
master taught amongst his followers. As the true specialist in that regard, alWāsițī was therefore probably largely self-reliant when he taught Sufism in Damascus.

As such, there are indications that he would have sometimes fundamentally disagreed with Ibn Taymiyya's opinions, especially with regard to certain Sufi authorities. Ibn Rajab relates that "[al-Wāsițī] and a group of the elite of [Ibn Taymiyya's] companions would sometimes criticize the shaykh for his [negative] remarks about some of the great and eminent imams or the folk of withdrawal and isolation (ahl al-takhallī wa-al-inqițā $)$."164 The latter category is undoubtedly meant as a reference to those Sufis who in spite of their respected status among traditionalists were nevertheless censured by Ibn Taymiyya. One such Sufi al-Wāsițī will surely have defended against his shaykh's sharp tongue is the Hanbalī master 'Abd Allāh al-Anșārī al-Harawī (d. 481/1089). While Ibn Taymiyya used to extol this Sufi sage earlier in his career, he later came to censure him for his system of stages on the Sufi way, which he considered baseless. ${ }^{165} \mathrm{Al}-W a \bar{s} i t \underline{1}$, on the other hand, appears to have consistently viewed al-Harawi as one of the great Sufis of his respective age. ${ }^{166}$

The observations we have thus far made throw a whole new light on the spiritual side of Ibn Taymiyya's leadership in his jamā'a. While it has been argued by Éric Geoffroy that al-Wāsițīs work testifies that the Hanbalī shaykh al-Islām must have fulfilled the role of spiritual guide for Sufis, our study has offered no conclusive evidence to support this assumption. ${ }^{167}$ On the contrary, we have come across several indications suggesting that it would rather have been al-Wāsitị who fulfilled this role, clearly with the approval of Ibn Taymiyya himself. I must stress that I am not thereby claiming that spiritual counseling and guidance was absent from Ibn Taymiyya's function as the leader of their Damascene jamāa $a$. We have already noted that his daily routine reflected the lifestyle typical of the Hanbali zuhhäd. But it was precisely his ability to com-

\footnotetext{
164 Ibn Rajab, Dhayl, vol. 4, p. 505 .

165 Al-Dhahabī, Tärīkh, vol. 33, p. 55. For Ibn Taymiyya's censure of al-Harawī, see for instance his commentary on al-Jīlānīs Futūh al-ghayb, in MF, vol. 10, p. 487; and also his al-Radd 'alà al-Shādhilī fì Hỉzbayhi wa-mā șannafahu fì ādāb al-țarīq, ed. 'Alī b. Muhammad al'Imrān (Mecca: Dār al-'ālam al-fawāìd li-al-nashr wa-al-tawzī', 2009), p. 120.

166 Al-Wāsițī, Madkhal ahl al-figh, p. 52; Mìzān al-shuyūkh, p. 235; Qā'ida fì sulūk al-awliyā', p. 168. It is worthwhile noting that it has since long been established that al-Wāsițī was not the only one of Ibn Taymiyya's inner circle who had a dislike for his shaykh's harsh attitude towards those he criticized. Al-Dhahabī, too, on numerous occasions expresses his annoyance with Ibn Taymiyya's habit to occasionally degrade his opponents in matters of religion. On this, see: Bori, "A New Source," pp. 326-328; and: Donald P. Little, "Did Ibn Taymiyya Have a Screw Loose?” Studia Islamica, No. 41 (1975): pp. 107-109.

Geoffroy, "Le traité de soufisme," p. 101.
} 
bine scholarly erudition with a profound consciousness of the deeper spiritual implications of his knowledge that led al-Wāsiți to recognize him as a complete master of the inward and outward dimension of Islam - though never as a Sufi master. ${ }^{168}$ The fact that he referred to Ibn Taymiyya as his spiritual guide (murshid), and to himself and the other members of their jama'a as the shaykh's aspirants (murieds), should therefore be understood against the background of his own identity as a Sufi, in light of which it was only natural to use such terminology to describe their relationship. ${ }^{169}$ It is not enough to assume that Ibn Taymiyya himself would have used these terms to describe his position vis-à-vis his disciples.

Having established what role al-Wāsițī had taken upon himself in Damascus, we will now seek to establish what can be said of the jamáa $a$ in which he fulfilled this role. We will do this through a brief study of what the relevant primary sources tell us about each individual member of Ibn Taymiyya's circle who is known to have been connected to our Iraqi Sufi, at least five of whom evidently took him as their shaykh in Sufism. This will allow us to recognize several more characteristics of their group identity and get an image of the nature of their relationships.

Seven of al-Wāsițîs Taymiyyan companions can be identified through a letter he had sent them (from which we have quoted before) ${ }^{170}$ and four others can be identified on the basis of biographical dictionaries and/or their own writings. ${ }^{171}$ The list of individuals from Ibn Taymiyya's circle is then as follows:

1. Taqī al-Dīn Aḥmad Ibn Taymiyya (661-728/1263-1328)

2. 'Imād al-Dīn Aḥmad al-Wāsițī (657-711/1259-1311)

3. 'Alam al-Dīn (or Bahā' al-Dīn) al-Qāsim b. Muḥammad al-Birzālī (665739/1267-1339)

4. Taqī al-Dīn 'Umar b. 'Abd Allāh b. Shuqayr al-Ḥarrānī (666-744/12681343)

168 Al-Wāsițī, al-Tadhkira, p. 47.

169 Al-Wāsițîs view of Ibn Taymiyya as a complete shaykh and his use of Sufi language in relation to Ibn Taymiyya has been noted by Bori, "Ibn Taymiyya wa-Jamāatuhu," pp. 27-28. See also Geoffroy, "Le traité de soufisme," p. 101. Both base themselves on al-Wāsiți’s alTadhkira, p. 45 .

170 Al-Wāsițī probably sent this letter to these individuals when they were in Egypt with Ibn Taymiyya, who had been summoned to Cairo by Sultan al-Nāșir in 705/1306. We know that when the shaykh returned to Damascus seven years later, about a year after al-Wāsițīs passing, he was accompanied by his brothers and a group of his companions (jamāc $\mathrm{a}$ min așhābihi), cf. Ibn Rajab, Dhayl, vol. 4, p. 518.

171 This list consists exclusively of members of the Taymiyyan jamāa $a$ who are known to have been linked to al-Wāsițî. It thus omits those individuals for whom I have not been able to establish a link with him (such as al-Mizzī, for instance). 
5. Shams al-Dīn Muhammad b. 'Abd al-Ahad al-Āmidī (661343-8621/743-6)

6. Shams al-Dīn Abū 'Abd Allāh Muhammad al-Dhahabī (673-748/ 12741348)

7. Fakhr al-Dīn Muḥammad b. Muḥammad Ibn al-Ṣāigh (674-748/12751347)

8. Sharaf al-Dīn Muhammad Ibn al-Munajjā al-Tanūkhī (675-724/12761324)

9. Zayn al-Dīn Abū Muḥammad 'Abd al-Raḥmān al-Ba'labakkī (675734/1276-1333)

10. Nūr al-Dīn Muhạmmad b. Muḥammad Ibn al-Șā̄igh (676-749/1277-1348)

11. Ibrāhīm b. Muḥammad al-Qawwās al-Dimashqī (677-761/1278-136o)

12. Shams al-Dīn Muhammad b. Abī Bakr Ibn Qayyim al-Jawziyya (691751/1292-1350)

13. Sharaf al-Dīn Muhammad b. Sacd Allāh al-Harrānī (d. 723/1323)

We will begin by looking at the activities of the above individuals and see whether these can be connected to specific localities within Damascus. Of the eleven companions and disciples of al-Wāsițī, at least eight attended hadìth auditions under one or more of the shaykhs also attended by Ibn Taymiyya, as depicted in the following table. ${ }^{172}$

Ibn Taymiyya's shaykhs of hadith

\begin{tabular}{|c|c|c|c|c|c|c|c|}
\hline Members of Ibn Taymiyya's circle & $\frac{1=}{3}$ & 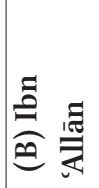 & 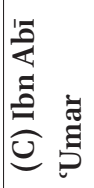 & 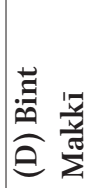 & (ี己 & 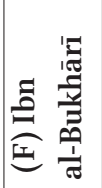 & 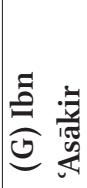 \\
\hline (3) al-Birzālī & $\mathrm{x}$ & $\mathrm{x}$ & $\mathrm{x}$ & & & $\mathrm{x}$ & $\mathrm{x}$ \\
\hline (4) Taqī al-Dīn al-Harrān̄̄ & $\mathrm{X}$ & & & $\mathrm{x}$ & $\mathrm{X}$ & $\mathrm{X}$ & \\
\hline (6) al-Dhahabī & $\mathrm{X}$ & $\mathrm{X}$ & $\mathrm{x}$ & & & $\mathbf{X}$ & $\mathrm{X}$ \\
\hline (7) Fakhr al-Dīn Ibn al-Ṣā'igh & & & $\mathrm{X}$ & & $\mathrm{x}$ & $\mathrm{X}$ & \\
\hline (8) Ibn al-Munajjā & & $\mathrm{x}$ & $\mathrm{x}$ & & & $\mathrm{X}$ & \\
\hline (10) Nūr al-Dīn Ibn al-Ṣāigh & & & & & & & $\mathrm{X}$ \\
\hline (11) Ibrāhīm al-Qawwās & & & & $\mathrm{x}$ & & $\mathrm{X}$ & $\mathrm{x}$ \\
\hline (13) Sharaf al-Dīn al-Ḥarrānī & & & & $\mathrm{x}$ & & $\mathrm{x}$ & \\
\hline
\end{tabular}

172 For a brief biographical notice on each of these hadith masters, see appendix 2, pp. 169170. For a list of Ibn Taymiyya's shaykhs, see: Ibn 'Abd al-Hādī, al- Uqūd, p. 19; Ibn Rajab, Dhayl, vol. 4, p. 493, and Ibn Taymiyya's $M F$, vol. 18, pp. 97-98, where he mentions Ibn 'Allān, saying that he heard hadīth from him in 68o/1281. 
If we recall the earlier-mentioned daily schedule of Ibn Taymiyya, where we saw that he would go to hadith auditions after sunrise with his companions, we should be open to the possibility that they attended at least some of the above shaykhs as a group. If this was indeed the case and we look at the locations where a few these shaykhs are said to have been based (as indicated in figure 19, p.167), then Ibn Taymiyya's jamā'a may have jointly frequented the Muzaffarī Mosque, the 'Umariyya madrasa, and the Dār al-Hadìth al-Ashrafiyya in alȘālihiyya, and the Dār al-Ḥadìth al-Ashrafiyya and the Hanbaliyya madrasa in the old city. If we then look at the locations where they themselves acquired teaching positions (also indicated in figure 19), we find that, with the exception of al-Āmidī, they were all based in the old city (the Umayyad Mosque, the Dār al-Hadìth al-Nūriyya and al-Sukkariyya, and the Hanbaliyya, Mismāriyya, Nafisiyya, and Dimāghiyya madrasas). We can thus observe that while they were certainly prepared to roam around Damascus for the sake of religious knowledge, they were primarily concentrated in the western part of the old city.

By Analyzing the biographical information provided in appendix 3 (pp. 170174), there are several more relevant observations to be made regarding the relationships between the members of the jama $\bar{a}^{c} a$. We can see that three of them were born in the mid-sixties and six in the mid-seventies, and therefore not much younger than Ibn Taymiyya, who was born in 661/1263. With the exception of Ibn al-Qayyim, who was born in the nineties, there was thus not a considerable age difference among them. In addition to the several shaykhs of hadith they probably attended as a group, they also appear to have taken knowledge from each other, and certainly not exclusively from Ibn Taymiyya. A case in point is al-Dhahabī, who heard hadìth from at least four other members of the jamā'a besides the shaykh al-Islām, and credits three of them with being his shaykhs, even though they were most likely peers. Another testament to that reality is, of course, al-Wāsiți himself, who, in spite of his role as their Sufi teacher, displays a deep sense of appreciation and reverence in the way he speaks of the Taymiyyan disciples he taught, indicative of mutual respect rather than strictly a master-disciple relationship. ${ }^{173}$ Add to that the fact that the biographical information on the members of the jamã $a$ shows that they all reached a certain degree of success as scholars in their own right, with some

173 I have added the titles of respect by which al-Wāsițīs earlier mentioned letter refers to seven of his companions from the jama $\bar{a}^{c} a$ in their respective biographies in appendix 3 . For the original Arabic, see: al-Wāsițī, al-Tadhkira, pp. 21-23. While it may be argued that the way he addresses them is purely rhetorical convention, I believe our study in the previous section has convincingly shown that al-Wāsițī did genuinely revere his Damascene companions. 


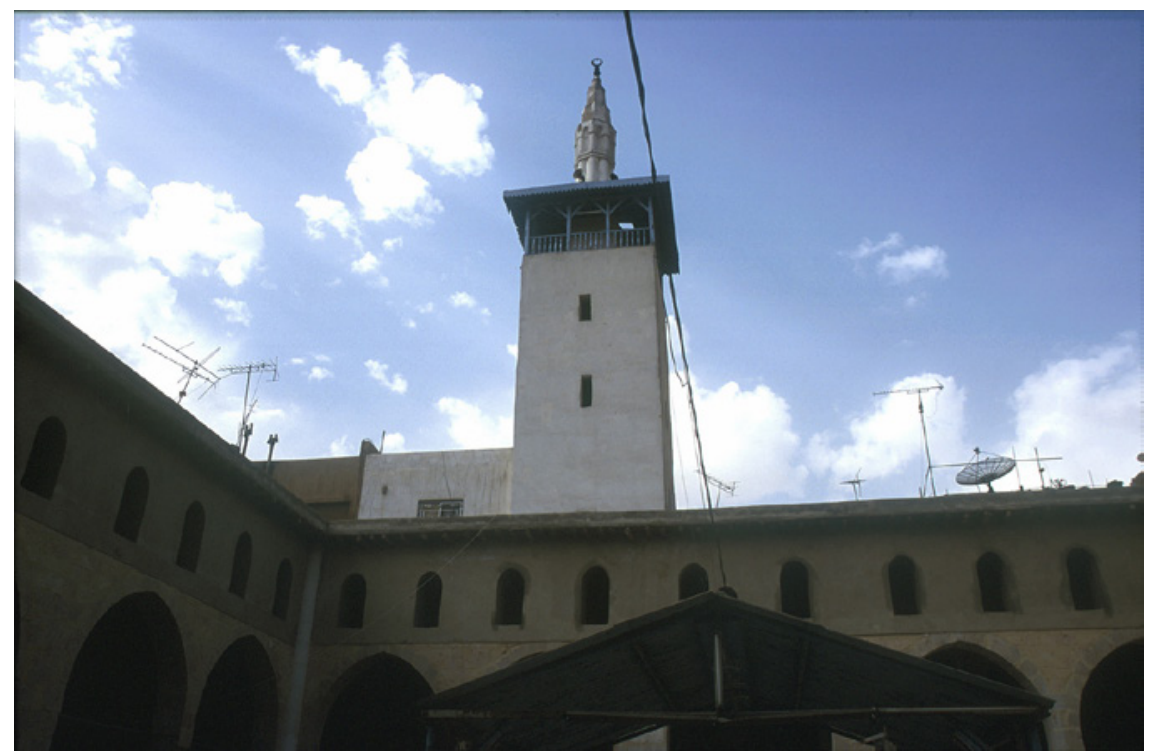

FIGURE 11 The great Muẓaffarī Mosque (a.k.a. Jāmi' al-Ḥanābila) in al-Ṣaliḥiyya, Damascus (number 1 on the map on p. 167).

(C) ROSS BURNS, <HTTP://MONUMENTSOFSYRIA.COM>

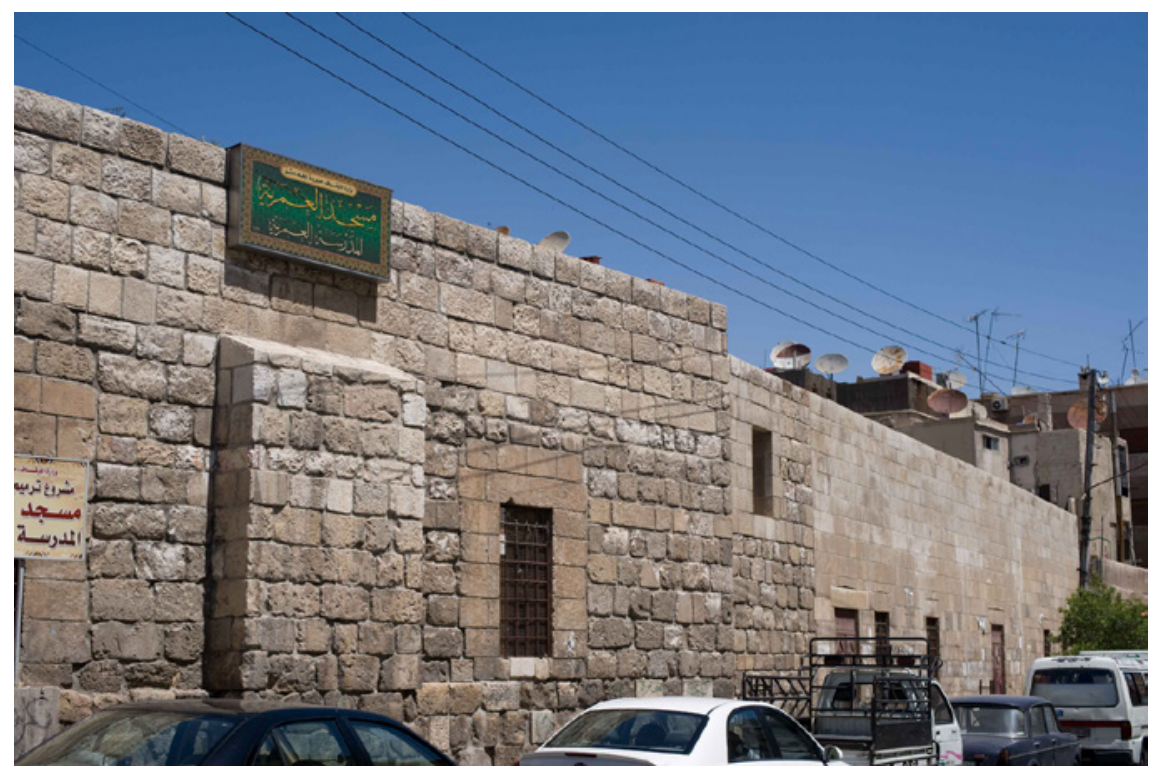

FIGURE 12 Al-Madrasa al-'Umariyya in al-Ṣālihiyya, Damascus (number 2 on the map on p. 167).

(C) ROSS BURNS, <HTTP://MONUMENTSOFSYRIA.COM> 


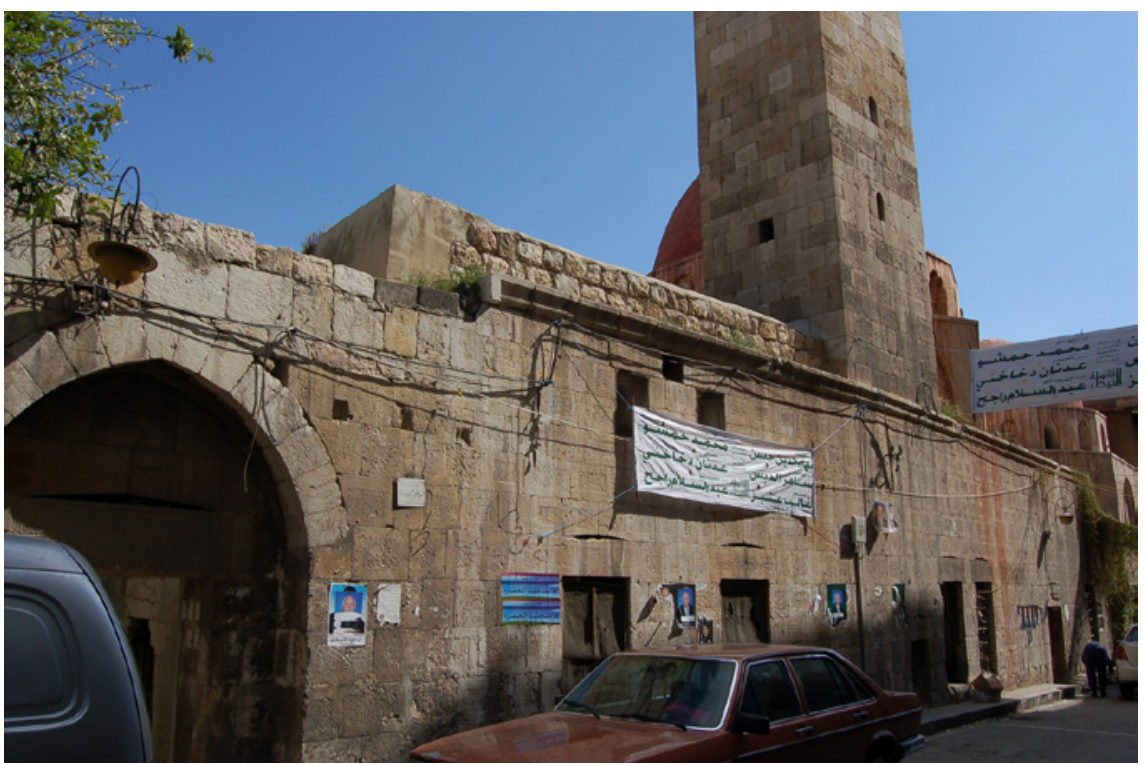

FIGURE 13 On the left is the gate of Dār al-Hadīth al-Ashrafiyya al-Barrāniyya with al-Madrasa al-Murshidiyya to its right, in al-Ṣālihịyya, Damascus (number 5 on the map on p. 167).

(C) ROSS BURNS, <HTTP://MONUMENTSOFSYRIA.COM>

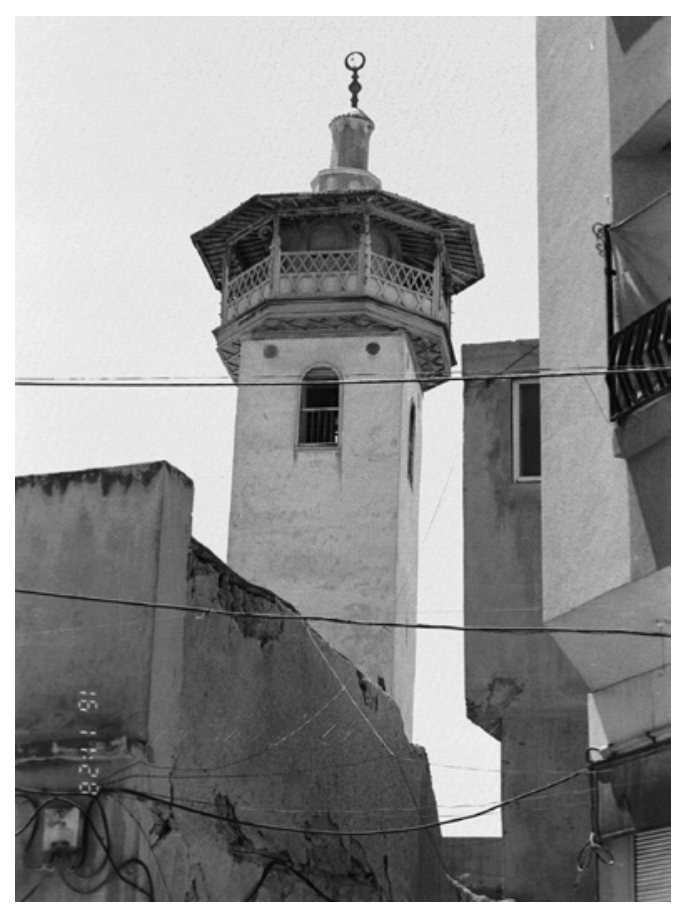

FIGURE 14

Minaret of the Karīmī Mosque in the Qubaybāt quarter of Damascus (number 16 on the map on p. 167). (C) ROSS BURNS, <HTTP://MONU MENTSOFSYRIA.COM $>$ 

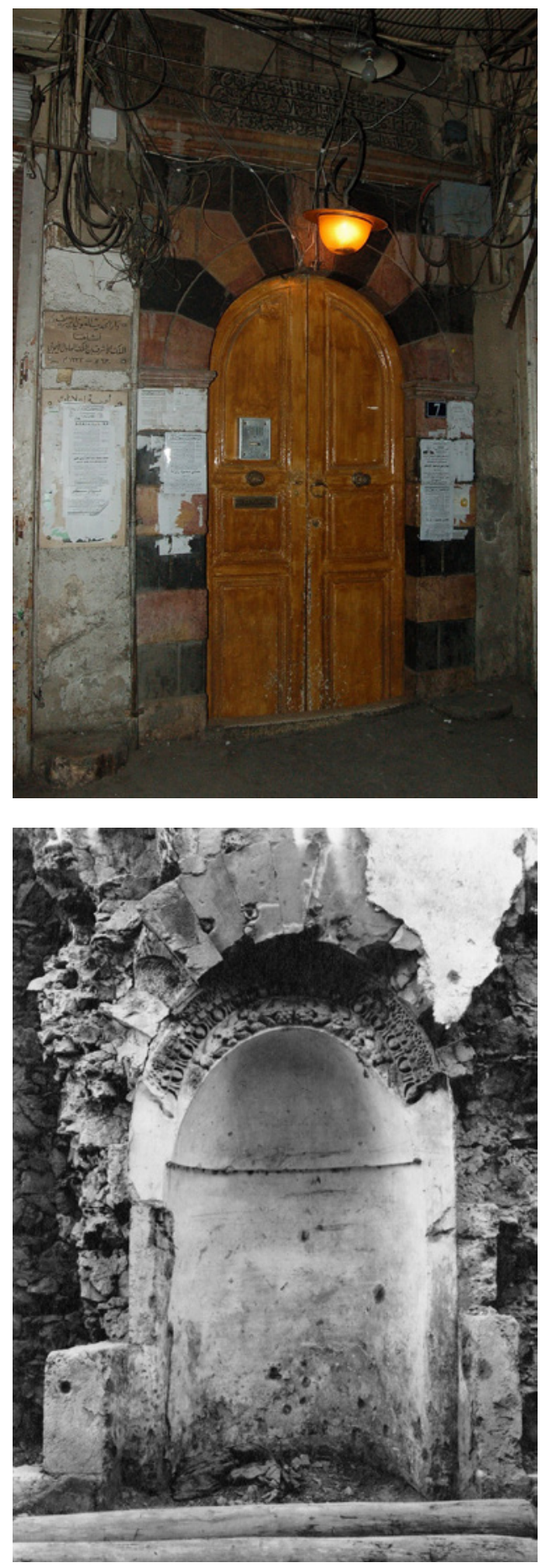

FIGURE 15

The gate of Dār al-Ḥadīth al-Ashrafiyya in the old city of Damascus (number 7 on the map on p. 167).

(C) ROSS BURNS, <HTTP://MONUMENTSOFSYRIA.COM $>$

\section{FIGURE 16}

The remains of the carved mihrāb of Dār al-Ḥadīth al-Nūriyya in the old city of Damascus (number 12 on the map on p. 167).

(C) ASHMOLEAN MUSEUM, UNIVERSITY OF OXFORD. IMAGE COURTESY OF SPECIAL COLLECTIONS, FINE ARTS LIBRARY, HARVARD UNIVERSITY 

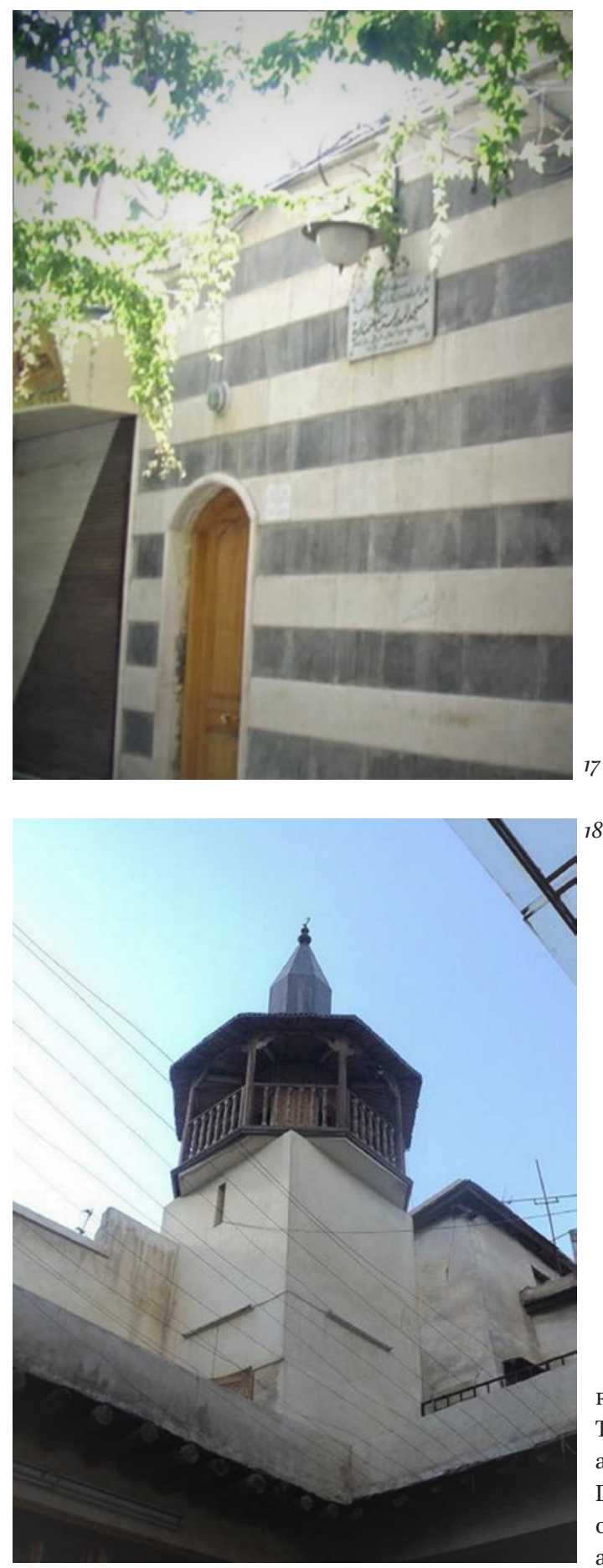

\section{8}

FIGURES 17 AND 18

The gate and minaret of al-Madrasa al-Mismāriyya in the old city of Damascus. (number 10 on the map on p. 167). Pictures courtesy of 'Imād al-Armashī 


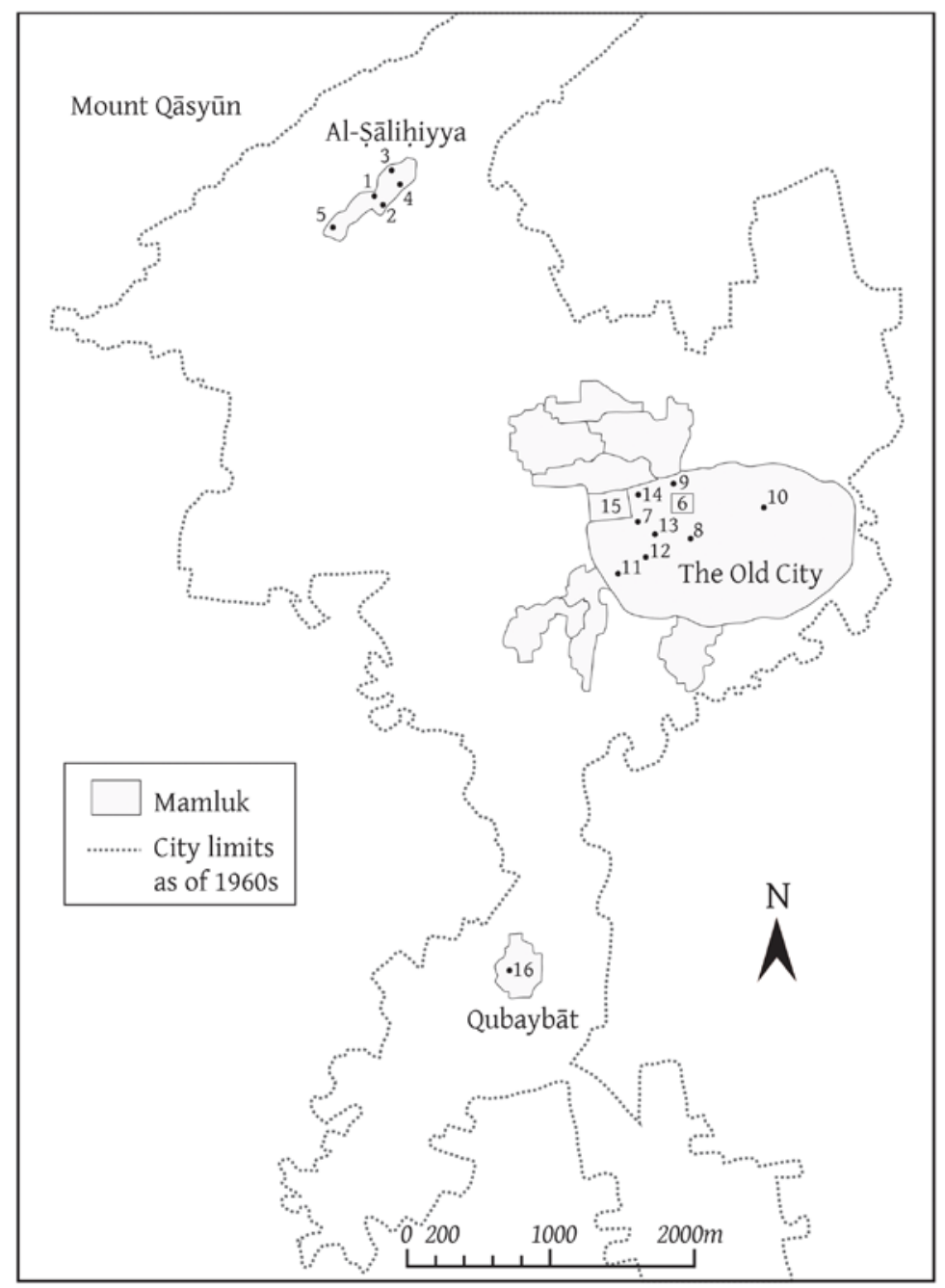

FIGURE 19

Above: A map of Mamluk Damascus with the mosques and madrasas ran and/or attended by traditionalists. Map adapted from Ross Burns, Damascus: A History (London/New York: Routledge, 2007), p. 310. Below: The names of the institutions followed by references between brackets: with the numbers referring to members of Ibn Taymiyya's circle, and the letters referring to the scholars they themselves attended to hear hadith (numbers and letters are in accordance with the sequence as found above and in appendix 2 and 3 )

\section{al-Ṣāliḥiyya:}

1. al-Jāmi` al-Muẓaffarī (C)

2. al-Madrasa al-'Umariyya (F)

3. al-Madrasa al-Diyāiiyya

4. al-Madrasa al-Ṣaḥibiyya

5. Dār al-Ḥadīth al-Ashrafiyya al-

Barrāniyya $(\mathrm{C})$

Old City:

6. Umayyad Mosque (1)

7. Dār al-Ḥadīth al-Ashrafiyya (A)
8. al-Madrasa al-Jawziyya

9. al-Madrasa al-Hanbaliyya al-Sharīfiyya $(\mathrm{D} / 1,2)$

10. al-Madrasa al-Mismāriyya (D/8)

11. Dār al-Hadīth al-Sukkariyya $(1,6)$

12. Dār al-Hadīth al-Nūriyya (3)

13. al-Madrasa al-Nafìsiyya (3)

14. al-Madrasa al-Dimāghiyya (10)

15. Citadel

Qubaybāt:

16. al-Jāmi` al-Karīmī (5) 
even acquiring considerable fame, we begin to get the impression that perhaps Ibn Taymiyya was not some figure that towered over them, but that we are dealing with a group of men who were first and foremost kindred spirits.

As I have argued earlier, I believe that it was their shared passion for traditionalism as the purest form of Islam that brought them together. They chose to do so under the leadership of Ibn Taymiyya because they recognized in him the traditionalist (Hanbalī) ideal of a complete master, who combined scholarship and piety. As a group they strove to attend auditions of hadith among the renowned shaykhs of Damascus together, they followed their leader wherever they could together, and they were willing (at least initially) to jointly suffer the consequences of his activism for the traditionalist cause.

To conclude, we will once more draw attention to the way normativity may be related to context. Our overview in section 2.1 of the situation in Damascus shortly before and during al-Wāsițī's lifetime has shown us that the traditionalist Hanbalīs had claimed it as their new capital. Although they certainly did not dominate the city, and there was occasional tension between them and scholars from other schools of law/theology, they did successfully establish themselves in its religious landscape. We may recall, for instance, that the combination of scholarship and piety of the Maqdisīs appears to have greatly appealed to many Damascenes. In such a setting it seems quite natural that a group such as that of Ibn Taymiyya could emerge and gain a following. After all, in the traditionalist community of Damascus, their religiosity would have been considered quite normative and admirable, even. ${ }^{174}$ It is therefore not surprising that, as a self-proclaimed traditionalist, al-Wāsiți considered his assimilation into the jamā'a a shot from his nadir in Cairo to the zenith he had been pursuing most of his adult life. For him, it marked the end of his physical journey.

Since we have constantly considered how the Sufism of the previous groups he had accompanied may be related to notions of normativity of the respective context in which they operated, we should likewise consider how this is the case for the formulation of Sufism he himself preached amidst the Taymiyyan circle. This will require a thorough examination of his own Sufi doctrine, for which we now turn to part 2 of our study.

174 I am aware of the later controversies in traditionalist circles surrounding some of Ibn Taymiyya's teachings, which Caterina Bori has covered in her article "Ibn Taymiyya waJamā'atuhu," pp. 23-43. However, it should be noted - as Bori also does - that this was a later development in Ibn Taymiyya's career. During the years al-Wāsițī spent with him he was in all likelihood still very much a rising star in the city's traditionalist community. 


\section{Appendix 2: The Hadith-Scholars Attended by the Taymiyyan Circle}

A. Amìn al-Dìn al-Qāsim b. Abì Bakr al-Irbilī (d. 680/1281): A muhaddith rank hadìthscholar, ${ }^{175}$ who taught at the Dār al-Hadīth al-Ashrafiyya in the old city of Damascus. ${ }^{176}$

B. Shams al-Dìn Abū al-Ghanāim al-Muslim Ibn 'Allān (d. 1282/o86): A Damascene musnid rank hadïth-scholar ${ }^{177}$ and traditionalist in creed who taught in Baalbek and Damascus. ${ }^{178}$

C. Shams al-Dīn Ibn Abī 'Umar 'Abd al-Raḥmān al-Maqdisī (d. 682/1283): The earliermentioned cousin of Muwaffaq al-Dīn. He was considered the most knowledgeable of his time in the Hanbali school. He was Friday preacher of the Muzaffarī Hanbalī Mosque and attained directorship over the Dār al-Ḥadìth al-Ashrafiyya al-Barrāniyya of the Șālihịyya, where he functioned as teacher and judge. ${ }^{179}$

D. Zaynab Bint Makkī b. 'Alī al-Harrānī (d. 688/1289): A Hanbalī zāhida and musnida rank hadith-scholar who appears to have taught at the madrasa al-Hanbaliyya al-sharīfiyya and al-Mismāriyya, both in the old city.180

E. Badr al-Dìn Abū al-'Abbās Aḥmad Ibn Shaybān (d. 689/129o): A musnid rank hadìth-scholar who lived in the Șāliḥiyya, from where he transmitted Ibn Hanbal's Musnad. 181

175 A muhaddith is a specialist who has reached the second rank in hadith scholarship. This is someone who is knowledgeable in the hadith's strengths and weaknesses when it comes to isnād and text, and who is familiar with the six canonical collections and has memorized at least a thousand of their hadiths, cf. Mohammed Hashim Kamali, A Textbook of Hadìth Studies: Authenticity, Compilation, Classification and Criticism of Hadith (Markfield, Leicestershire: Islamic Foundation, 2005), pp. 63-64.

176 On him, see: al-Ṣafadī, al-Wāfì, vol. 24, p. 86; Ibn al-'Imād, Shadharāt, vol. 7, p. 641. Note that there were two schools with the name Dār al-Ḥadith al-Ashrafiyya, one in the old city and one in the Șālihiyya. For al-Irbilī’s teaching activity at this institution, see: alDimashqī, al-Dāris, vol. 1, p. 21.

177 A musnid is a specialist who has reached the first rank in hadith scholarship. This is someone who transmits hadïth, even though he may not be knowledgeable in its isnäd or its meaning, cf. Kamali, $A$ Textbook, p. 64.

178 He was probably a Shāfi īi I base his traditionalism on al-Dhahabỉ's entry on him, where it is stated that he loved the Ahl al-Hadìth, cf. al-Dhahabī, Tārīkh, vol, 5o, p. 373; and also al-Ṣafadī, al-Wāfì, vol 25, pp. 326-327.

179 Al-Dimashqī, al-Dāris, vol. 1, pp. 36-37; Ibn Rajab, Dhayl, vol. 4, pp. 179-180.

180 Al-Șafadī, al-Wāfì, vol. 15, pp. 42-43; al-Dhahabī, Tārīkh, vol. 51, pp. 327-328. For her teaching activity, see: al-Dimashqīi, al-Dāris, vol. 2, p. 58, and: Stefan Leder, Yāsīn Muhammad al-Sawwās, and Ma’mūn Șāğarğī, Mu'ğam al-samāāàt al-dimašqiyya 550-750 h. / Les certificats d'audition à Damas: 1155-1349 (Damascus: Institut français de Damas, 1996), p. $5^{\circ}$. She is listed as a Ḥanbalī scholar by Bakr b. 'Abd Allāh Abū Zayd, 'Ulamā’al-ḥanābila (Riyad: Dār Ibn al-Jawzī, 2001), p. 508.

181 Al-Dhahabī, al-Tbar, vol. 3, p. 358; Ibn al-Imād, Shadharāt, vol. 7, p. 681; Ibn Kathīr, alBidāya, vol. 13, p. 361 . 
F. Fakhr al-Dìn 'Al̄̄ Ibn al-Bukhārī al-Maqdisī (d. 69o/1291): A zāhid, Hanbalī jurist, and muhaddith rank hadith-scholar who taught at the 'Umariyya Hanbali madrasa in the Șālihiyya. ${ }^{182}$

G. Sharaf al-Dīn Ahmad b. Hibat Allāh Ibn Asākir (d. 699/130o): A musnid rank hadith-scholar who taught in the old city. He was from the famous Damascene Banū 'Asākir, a Shāfīì-Ash'arī family. ${ }^{183}$

\section{Appendix 3: Biographies of al-Wāsițîs Companions from Ibn Taymiyya's Circle}

3. 'Alam al-Dīn (or Bahā' al-Dìn) al-Qāsim b. Muhammad al-Birzālī (665-739/12671339): A Damascene historian, traditionalist Shāfi '̄, and hadìth specialist who reached the rank of haffiz. ${ }^{184}$ When he was approximately eight years old he began studying under his father. He soon sat with the distinguished hadith-scholars of Damascus, such as Ibn 'Allān, Ibn al-Bukhārī, al-Irbilī, Ibn 'Asākir, and Ibn Abī 'Umar. ${ }^{185}$ Although he credited Ibn Taymiyya with being one of his shaykhs, the two would probably have been closer to peers. ${ }^{186}$ In his dictionary of the shaykhs he studied with, al-Birzāli describes al-Wāsițī as follows: "He was a pious man and a knower [of God] (rajulun șăliḥun 'ärifun), given to asceticism and worship, who abstained from this world. He has solid words about authentic Sufism (al-tașawwuf al-șahịh)." ${ }^{187}$ Al-Birzālī made a good career for himself, teaching hadìth at several madrasas in the old city and eventually attaining directorship over the Dār al-Hadīth al-Nūriyya and the Nafisiyya madrasa. ${ }^{188}$

4. Taqì al-Dìn 'Umar b. 'Abd Allāh Ibn Shuqayr al-Harrānī (666-744/1268-1343): A Hanbali jurist and hadìth-scholar from Damascus who is mentioned as one the elite

182 Ibn Rajab, Dhayl, vol. 4, pp. 242-249.

183 Al-Dhahabī, Tārīkh, vol. 52, pp. 389-39o; Ibn al-'Imād, Shadharāt, vol. 7, p. 778.

184 A hăfiz is a specialist who has reached the third rank in hadith scholarship. It is someone with a yet even wider knowledge of hadith than the muhaddith. Cf. Kamali, A Textbook, p. 64 .

185 Al-'Asqalānī, al-Durar al-kamina, vol. 4, pp. 277-279; al-Subkī, Ṭabaqāt al-shāfíìya, vol. 10, pp. 381-383; Ibn Kathīr, al-Bidāya, vol. 14, pp. 216-217; Ibn Rajab, Dhayl, vol. 4, p. 181; al-Dhahabī, Tārīkh, vol. 52, p. 38o; Ibn Qāḍī Shahba, Țabaqāt, vol. 2, pp. 279-28o.

186 Al-Birzālī mentions Ibn Taymiyya in his Mujam al-shuyūkh, a work that is unfortunately lost. However, the shaykh al-Islām's entry is preserved in Shams al-Dīn Muhammad alQaysī Ibn Nāșir al-Dīn, al-Radd al-wāfir, ed. Zuhayr al-Shāwīsh (Beirut: al-Maktaba alislāmī, 2010), p. 121. Ibn Taymiyya appears to have valued al-Birzālī's evidently superior talent in the field of hadìth. Ibn Kathīr relates that the Hanbalī shaykh alluded to his sharp memory, saying: "al-Birzālì's transmission [of hadìth] is engraved in stone" (naqlal-Birzāale naqrun fi hajar), cf. al-Bidāya, vol. 14, p. 217.

187 Ibn Rajab cites the entry of al-Wāsiți from al-Birzālī’s Mujam al-shuyūkh in:Dhayl, vol. 4, p. 382 .

188 Al-Dimashqī, al-Dāris, vol. 1, pp. 83 \& 85 . 
members of Ibn Taymiyya's circle. He is the first disciple to be mentioned in al-Wāsiți’s letter, where he is addressed as "the most outstanding notable, the eminent scholar, the pride of the hadith specialists, the light of those devoted to God, the one who has turned himself to God ..."189 In jurisprudence he memorized al-Muharrar fi al-fiqh by Ibn Taymiyya's grandfather Majd al-Dīn, and in hadìth he sat with al-Irbilī, Zaynab Bint Makkī, Ibn Shaybān, and Ibn al-Bukhārī. ${ }^{190}$

5. Shams al-Dīn Muhammad b. 'Abd al-Ahad al-Āmidī (661343-8621/743-6): Also referred to in the sources as Ibn al-Zarīr and Ibn al-Razīz. He is the second disciple to be mentioned in al-Wāsițī's letter, where he is addressed as "the most outstanding shaykh, the eminent scholar, the ascetic traveler of the spiritual way (al-sālik al-nāsik), who combines knowledge with practice. Due to his praiseworthy qualities he is dressed in the most beautiful of garbs ..." ${ }^{191} \mathrm{Al}-\bar{A}$ midī was born in the city of Amida (present-day Diyarbakır, Turkey) and settled in Damascus, where he became one of Ibn Taymiyya's companions. He was regarded as one of the elite members of his circle. Apart from his function as preacher $(k h a t ̦ i ̄ b)$ of the Jāmic al-Karīmī in the Qubaybāt quarter south of Damascus, little more is known of him. ${ }^{192}$

6. Shams al-Dīn Abū 'Abd Allāh Muḥammad al-Dhahabì (673-748/1274-1348): By now we have come across al-Dhahabī's name numerous times. Like al-Birzālī, he was a Damascene historian, Shāfiì jurist, and hadìth specialist who reached the rank of hăfiz. According to his student al-Subkī, he was strongly inclined towards the theological opinions of the Hanbalīs, with great disregard for the Ash'arīs, of whom he would speak well reluctantly. ${ }^{193}$ This attitude is indeed reflected in many of his own writings, which are full of praise for traditionalist theology (often simply referred to as the method of the Salaf) and negative remarks towards kaläm. ${ }^{194}$ He took hadith from Ibn al-Bukhārī, Ibn Abī 'Umar, Ibn 'Allān, al-Irbilī, and Ibn 'Asākir, and in Ibn Taymiyya's circle from the shaykh al-Islām himself, al-Birzalī (who had guided him to the study of hadìth), Sharaf al-Dīn al-Ḥarrānī, Sharaf al-Dīn Ibn al-Munajjā, and perhaps also Nūr al-Dīn Ibn al-Ṣā’igh. ${ }^{195}$ He had a successful career in Damascus, and after the passing of

189 Al-Wāsițī, al-Tadhkira, p. 21.

190 Taqī al-Dīn Muḥammad Ibn Rāfí, al-Wafayāt, ed. Șāliḥ Mahdī 'Abbās \& Bashshār 'Awwād Márūf (Beirut: Mu’assasat al-risāla, 1982), vol. 1, pp. 461-462; Ibn Nāṣir al-Dīn, al-Radd alwäfir, p. 115; Al-Dhahabī, Tärīkh, Vol. 49, p. 233.

191 Al-Wāsițī, al-Tadhkira, p. 21.

192 Al-Asqalānī, al-Durar al-kāmina, vol. 5, p. 237; Ibn Kathīr, al-Bidāya, vol. 14, p. 239.

193 al-Subkī, Țabaqāt al-shäficiyya, vol. 9, pp. 100-103.

194 See for instance al-Dhahabī's Siyar, vol. 18, p. 514 where he compliments al-Harawì's Kitāb al-fārū $q$ for its chapter on the Hanbalī position regarding the divine attributes, and p. 510 where he defends al-Harawī as "a traditionalist man (rajulun athariyyun) devoted to affirming the texts on the divine attributes, very averse to kaläm and its practitioners."

195 For his shaykhs, see: al-Subkī, Ṭabaqāt al-shäfíiyya, vol. 9, pp. 101-102; al-Dhahabī's dictionary of his shaykhs, Mujjam al-shuyūkh al-kabìr, ed. Muḥammad al-Ḥabīb al-Hīla 
Ibn Taymiyya he obtained directorship of the Dār al-Hadīth al-Sukkariyya. ${ }^{196}$ Interestingly, al-Dhahabì was initiated into the Suhrawardiyya in Cairo by the hadith-scholar and Sufi Ḍiyā' al-Dīn 'Īsā al-Anșārī, who passed away in 696/1297. ${ }^{197}$ This means that he must have already been something of a Sufi before he sat with al-Wāsițī. As for our Iraqi Sufi, al-Dhahabī was evidently impressed by him, stating that he had benefitted from his classes in Sufism and did not know of anyone in Damascus who could equal him in this field. ${ }^{198}$

7. Fakhr al-Din Muhammad b. Muhammad Ibn al-Ṣäigh (674-748/1275-1347): A traditionalist Shāfíi jurist from Damascus who is mentioned as an elite member of Ibn Taymiyya's circle. He is the sixth disciple to be mentioned in al-Wāsițì's letter, where he is addressed as "the notable, the brother, the devout, righteous, and reliable scholar, excelling in his trustworthiness, endowed with good manners and faith, firm in following the Sunna ..."199 Among others, he took hadìth from Ibn Abī 'Umar, Ibn Shaybān, and Ibn al-Bukhari. In 742/1341 he was invested with the jurisdiction over the Mamluk troops ( $q a d \bar{a}^{\prime}$ al-'așākir), most likely in Damascus, where he also passed away some six years later. ${ }^{200}$

8. Sharaf al-Dīn Muhammad Ibn al-Munajjā al-Tanūkhī (675-724/1276-1324): A Hanbalī jurist and hadīth scholar from Damascus who is mentioned as an elite member of Ibn Taymiyya's circle. He is the third disciple to be mentioned in al-Wāsiți's letter, where he is addressed as "the notable, the brother, the eminent scholar, the ascetic traveler of the spiritual way, the righteous devout servant, whose feature is that his

(al-Ṭāiif, Maktabat al-ṣiddīq, 1988), vol. 2, pp. 13-14 (Ibn al-Bukhārī), vol. 1, pp. 374-375 (Ibn Abī 'Umar), vol. 2, p. 340 (Ibn 'Allān). Al-Birzālī had encouraged al-Dhahabī to study Prophetic tradition, telling him that he has the handwriting of a hadith scholar, cf. alDhahabī, Mújam, vol. 2, pp. 115-117. In his al-Mucjam al-mukhtașs, p. 23o, al-Dhahabī relates that Sharaf al-Dīn al-Harrānī was a companion of his (șăhibī $)$ who transmitted hadiths to him on the authority of Ibn al-Bukhārī. In his Mújam al-shuyūkh, vol. 2, pp. 289-29o, al-Dhahabī mentions Sharaf al-Dīn b. al-Munajjā as one of his shaykhs from whom heard hadìth. In his al-Tbar, vol. 4, p. 150, al-Dhahabī refers to Nūr al-Dīn Ibn alṢāiigh as "our shaykh."

196 Al-Dimashqī, al-Dāris, vol. 1, p. 59.

197 As attested to by al-Dhahabī himself in: Mujam al-shuyūkh, vol. 2, pp. 87-88, and: Siyar, vol. 22, p. 377 .

198 Al-Dhahabī always refers to al-Wāsițī as "our shaykh," often accrediting him as an 'ārif, cf. his Kitāb tadhkira, vol. 3, p. 130 \& vol. 4, 191; Dhayl Tärīkh, p. 126; Tärīkh, vol. 44, p. 393, vol. 48, p. 274, vol. 51, p. 256, \& vol. 52, p. 401; Mújam al-shuyūkh, vol. 1, pp. 29-30; al-Tibb alnabawī, wa bi-ākhirihi fașl fì al-samā', ed. Muhammad 'Abd al-Raḥmān al-Mar'ashlī (Beirut: Dār al-Nafā’is li-al-țibā'ah wa-al-nashr wa-al-tawzī', 2004), p. 228; Ibn Rajab, Dhayl, vol. 4, p. 383 .

199 Al-Wāsițī, al-Tadhkira, p. 22.

200 Ibn Rāfí, al-Wafāyāt, vol. 2, pp. 42-43; Ibn Kathīr, al-Bidāya, vol. 14, p. 229; al-Dhahabī, Tärīkh, vol. 5o, p. 175 . 
heart's light shines on the surface of his face ..." ${ }^{201}$ His father, Zayn al-Dīn, was greatly impressed by Ibn Taymiyya, who had been one of his students. ${ }^{202}$ It is therefore perhaps not surprising that Sharaf al-Dīn attached himself to the shaykh al-Islām and became one of his loyal followers. He is known to have stood by his side and accompanied him on his travels. Among his shaykhs in hadìth were his own father, Ibn 'Allān, Ibn Ab̄̄ 'Umar, and Ibn al-Bukhārī. He heard the six canonical books of hadìth and the Musnad of Ibn Hanbal. Eventually he reached the degree of mufti and became teacher at the Mismāriyya madrasa of his family. ${ }^{203}$

9. Zayn al-Dīn 'Abd al-Raḥmān al-Ba labakkī (or al-Ba'lī) (675-734/1276-1333): A specialist in Hanbalī jurisprudence, a scholar of hadìth, and a Sufi, who is mentioned as an elite member of Ibn Taymiyya's circle. He is the fourth disciple to be mentioned in al-Wāsițī's letter, where he is addressed as: "the notable, the brother, the jurist, the outstanding eminent scholar, the pride of those who comprehend (fakhr al-muhas silin)..." 204 Although he was originally from Baalbek and passed away there as well, it is likely that he spent the majority of his scholarly career in Damascus. He accompanied al-Wāsiți in Sufism and mastered jurisprudence under the guidance of Ibn Taymiyya, until he became proficient in it and was permitted to issue fatwas. He taught at several madrasas and authored books in the fields of figh, hadith, and tașawwuf. ${ }^{205}$

10. Nür al-Dīn Muhammad b. Muhammad Ibn al-Șāigh (676-749/1277-1348): The younger brother of the earlier-mentioned Fakhr al-Dīn Ibn al-Ṣāigh and the fifth disciple to be mentioned in al-Wāsițī's letter, where he is addressed as "the notable, the brother, the eminent scholar, the ascetic traveler of the spiritual way, endowed with an excelling intellect, righteous works, ample tranquility, and abundant virtues ..."206 $\mathrm{He}$ studied under Ibn 'Asākir and is mentioned as an elite member of Ibn Taymiyya's circle. In Damascus he was invested with the jurisdiction over the Mamluk troops, with whom he traveled to Cairo. He later returned to Damascus and became a teacher at the Dimāghiyya madrasa, until he was appointed chief judge ( $q a \bar{a} d \bar{\imath} a l-q u d \bar{a} t)$ of the Shāfīis in Aleppo in 744/1343, an office he held until he passed away. ${ }^{207}$

\footnotetext{
201 Al-Wāsițī, al-Tadhkira, p. 22.

202 Ibn Rajab, Dhayl, vol. 4, p. 273.

203 Al-Dhahabī, Mu'jam, vol. 2, pp. 289; Ibn Rajab, Dhayl, vol. 4, pp. 456-459; al-'Asqalānī, alDurar al-kāmina, vol. 6, p. 18; Ibn Kathīr, al-Bidāya, vol. 14, pp. 133-134.

204 Al-Wāsițī, al-Tadhkira, p. 22.

205 Ibn Rajab, Dhayl, vol. 5, pp. 50-52, Ibn Kathīr, al-Bidāya, 14:194. For a more detailed biography, I refer the reader to the introduction to my article: "A Glimpse of Sufism," pp. 163166.

206 Al-Wāsițī, al-Tadhkira, p. 22.

207 Al-'Asqalānī, al-Durar, vol. 5, p. 495; note that al-Ṣafadī gives an incorrect date of birth in al-Wāfi, vol. 1, p. 249; al-Ṣafadī also offers a biography in Áyān al-'aṣr, vol. 5, pp. 199-200. For the Dimāghiyya, see: al-Dimashqī, al-Dāris, vol. 1, pp. 177-182.
} 
11. Ibrāhìm b. Muhammad al-Qawwās al-Dimashqī (677-761/1278-1360): His madhhab-affiliation is unknown, but he was a Sufi and a musnid rank hadīth-scholar. He took hadīth from Zaynab Bint Makkī, Ibn al-Bukhārī, and Ibn 'Asākir, and he also transmitted himself. Initially he had been a close disciple of Ibn Hūd, but he later renounced him and started following Ibn Taymiyya. In Sufism he accompanied (șahiba) al-Wāsițī, from whose guidance he is reported to have benefited. ${ }^{208}$

12. Shams al-Dìn Muhammad b. Abī Bakr Ibn Qayyim al-Jawziyya (691-751/1292-1350): A Damascene Hanbalī scholar and perhaps the most talented of Ibn Taymiyya's disciples. As seen from his date of birth, he was by far the youngest of al-Wāsiți's known students. If we are to believe Ibn Kathīr, Ibn al-Qayyim only started following Ibn Taymiyya upon the shaykh's return from Egypt in $712 / 1313 .{ }^{209}$ This would mean that he probably joined al-Wāsițī's classes on Sufism somewhere after the shaykh al-Islām left Damascus for Egypt in 705/1306. Of all the individuals we have thus far discussed, Ibn al-Qayyim became by far the most prolific author in the field of Sufism. Although little to nothing is known of his relationship with our Iraqi Sufi, he appears to have inherited his unfinished manuscript of a commentary on al-Harawīs Sufi treatise Manāzil alsäirìn. He quotes from it in his Shifä’ al-'alîl, wherein he refers to al-Wāsiți as "our shaykh."210

13. Sharaf al-Dīn Muhammad Ibn Najịh al-Harrānī (d. 723/1323): A Damascene Hanbali jurist and mentioned as an elite member of Ibn Taymiyya's circle. He is the seventh and final disciple to be mentioned in al-Wāsițīs letter, where he is addressed as "the dear and righteous brother, who seeks the path of His Lord and desires His contentment and love, the eminent scholar ..." ${ }^{211}$ He heard hadìth from Ibn al-Bukhārī, Zaynab Bint Makkī, and others, and also studied by himself. In jurisprudence his main teacher was Ibn Taymiyya, who also granted him the authority to give fatwas. Ibn Najị partook in many of his shaykh's trials and was at one point jailed with him.212

208 Al-'Asqalānī, al-Durar, vol. 1, p. 8o; Ibn Rāfic', al-Wafayāt, vol. 2, pp. 233-234.

209 Ibn Kathīr, al-Bidāya, vol. 14, p. 270; see also: Ibn Rajab, Dhayl, vol. 5, pp. 170-171.

210 Ibn Qayyim al-Jawziyya, Shifä’ al-'alïl fì masā'il al-qadăà' wa-al-qadar wa-al-hikma wa-alta'lïl (Beirut: Dār al-ma'rifa, 1978), p. 16. See also: Ibn Rajab, Dhayl, vol. 5, p. 383, and also: al-Dhahabī, al-Dhayl, p. 126.

211 Al-Wāsițī, al-Tadhkira, pp. 22-23.

212 Ibn Rajab, Dhayl, vol, 4, pp. 453-454. Ibn Nāșir al-Dīn, al-Radd al-wāfir, p. 45; al-'Asqalānī, al-Durar, vol. 5, p. 185; Ibn Kathīr, al-Bidāya, vol. 14, p. 127. 
PART 2

The Spiritual Journey (al-Sulūk) 